\title{
Fortification of micronutrients for efficient agronomic production: a review
}

\author{
Christian O. Dimkpa ${ }^{1} \cdot$ Prem S. Bindraban ${ }^{1}$
}

Accepted: 16 December 2015 / Published online: 7 January 2016

(C) INRA and Springer-Verlag France 2016

\begin{abstract}
Micronutrients are essential mineral elements required for both plant and human development. However, micronutrients are often lacking in soils, crop, and food. Micronutrients are therefore used as fertilizer to increase crop productivity, especially when the application of conventional NPK fertilizers is not efficient. Here, we review the application of micronutrients in crop production. Reports show that micronutrients enhance crop nutritional quality, crop yield, biomass production, and resiliency to drought, pest, and diseases. These positive effects range from 10 to $70 \%$, dependent on the micronutrient, and occur with or without NPK fertilization. We discuss the uptake by plants of micronutrients as nanosize particulate materials, relative to conventional uptake of ionic nutrients. We also show that packaging of micronutrients as nanoparticles could have more profound effects on crop responses and fertilizer use efficiency, compared to conventional salts or bulk oxides.
\end{abstract}

Keywords Agronomic fortification $\cdot$ Micronutrients $\cdot$ Crop nutrition $\cdot$ Crop productivity $\cdot$ Innovative fertilizers $\cdot$ Nutrient packaging

\section{Contents}

1 Introduction

2 Environmental and human aspects of micronutrients

2.1 Where do micronutrients come from?

2.2 Micronutrient deficiencies in soil

Christian O. Dimkpa

cdimkpa@vfrc.org; c_dimkpa@yahoo.com

1 Virtual Fertilizer Research Center (VFRC), 1901 Pennsylvania Avenue, NW, Washington, DC 20006, USA
2.3 Soil micronutrients in relation to human health

2.4 Micronutrients and the ecosystem

3 Roles of micronutrients in crops

3.1 Physiological roles and roles in abiotic and biotic stress mitigation

3.2 Roles of micronutrients in crop nutritional quality

3.3 Agronomic role (i): enhancement of biomass production and yield

3.4 Agronomic role (ii): enhancement of the efficiency of NPK

4 Revisiting micronutrients' uptake mechanisms for designing nutrient delivery strategies

4.1 Conventional uptake of nutrients: ions

4.2 Uptake of nanoparticulate nutrients

5 Influence of packaging on the bioactivity of micronutrients

6 Some ways forward

7 Concluding Remarks

8 Acknowledgments

9 References

\section{Introduction}

The task of feeding the global human population estimated at 9.6 billion by 2050 (United Nations 2013), combined with dietary transitions accompanying the change in human socioeconomic statuses, calls for the intensification of farming systems. Achieving this goal entails increasing the quantity and quality of crop production inputs such as water, seed, pesticide, and fertilizer (Tilman et al. 2011). As a crucial input in modern agriculture, fertilizers make an important contribution to the attainment of high crop yields (Erisman et al. 2008). Agricultural productivity increased in many of the regions that experienced the Green Revolution through the application of nitrogen, phosphorus, and potassium (NPK)-containing 
fertilizers. However, the lack of increase in productivity under less favorable biophysical conditions and the human nutrient deficiencies resulting from the consumption of crop produce with low dietary values have spurred the search for more sustainable and appropriate solutions to produce crops with higher yields and nutritional quality. Along this line, a reflection on the need for innovative fertilizers was recently presented by Bindraban et al. (2015).

Together with NPK, calcium $(\mathrm{Ca})$, magnesium $(\mathrm{Mg})$, and sulfur (S) are classified as essential macronutrients. The eight other essential nutrients constitute a distinct group of elements required by plants in very small amounts, described conventionally as micronutrients: namely (copper $[\mathrm{Cu}]$, iron $[\mathrm{Fe}]$, manganese [Mn], molybdenum [Mo], nickel [Ni], zinc $[\mathrm{Zn}])$, boron [B], and chlorine [Cl]). Still, other elements like selenium $(\mathrm{Se})$, silicon $(\mathrm{Si})$, and sodium $(\mathrm{Na})$ are regarded as nonessential, although they have been found to enhance growth and confer other benefits to plants (Datnoff et al. 2007; Marschner 2012). Collectively, these nutrients also play crucial roles in humans and, in many cases, dictate our physical and mental development and how we respond to diseases, especially the micronutrients. In fact, many of the enzymes, proteins, and other biological compounds that perform important metabolic functions in humans cannot accomplish such functions without micronutrients. Hidden hunger is a phenomenon borne out of the deficiency of micronutrients in human diets. In countries or regions where staple foods consist mainly of cereals, roots, and tubers grown in nutrient-poor soils, human micronutrient deficiency is widespread. Composite studies (dietary intake, blood sampling, and selfadministered questionnaires) from Nigeria, for example, indicate that 20,21 , and $32 \%$ of school children in Lagos were malnourished for $\mathrm{Fe}, \mathrm{Zn}$, and $\mathrm{Cu}$, respectively (Akeredolu et al. 2011). Indeed, Zn deficiency, with up to $50 \%$ prevalence in Sub-Saharan Africa, represents a major cause of loss in child cognitive skills, stunting, and even death, amounting to 450,000 globally per annum (McClafferty and Zuckermann 2015). It is estimated that by 2030 , a mere 15 years from now, the decline in global productivity arising from stunting, loss of cognitive skills, and other chronic illnesses will cost about \$35 trillion (Bereuter and Glickman 2015). However, micronutrient amendments into soil for crop uptake could contribute in lowering the impact of their deficiency in humans (Cakmak 2008), much like the case of Se in Finland, where fertilization of soils with Se-fortified NPK not only improved food crop yields but also improved daily Se intake and serum Se concentrations in the Finnish population (Ekholm et al. 2005).

To permit a concise discussion of this subject, this review will focus on $\mathrm{Cu}, \mathrm{Fe}, \mathrm{Mn}, \mathrm{Mo}, \mathrm{Ni}, \mathrm{Zn}, \mathrm{B}$, and $\mathrm{Cl}$, all of which share in common a low concentration requirement by both crops and humans. Thus, by no means is this review deemphasizing the importance of macronutrients in crops and humans, since a balanced nutrition requires the presence of all mineral nutrients, as well as vitamins. A comprehensive examination of the crop literature related to micronutrients hints to their multifunctionality in crop production. Such functions, including crop growth and yield enhancement, conferment of resistance/tolerance to diseases and abiotic stressors, and improvement of crop and seed nutritional quality, could have direct consequences for human and environmental health. Major research and investment efforts are warranted in order to increase our understanding of the agroecological complexities associated with the sustainable use of micronutrients and, thus, harness the full benefits of micronutrients to crops. Accordingly, the objective of this paper is to highlight the benefits of adopting micronutrients for the agronomic fortification of crops as fertilizers. To this end, we explored the interconnectedness of the role of micronutrients in plant growth and health, associated cobenefits of enhanced use of micronutrient fertilizers to soil and ecosystem health, and the implications for fertilizer redesign in terms of packaging and delivery to plants.

\section{Environmental and human aspects of micronutrients}

\subsection{Where do micronutrients come from?}

Most of the micronutrients are mined from under the earth's crust and processed for various industrial applications. Table 1 presents data (Unites State Geological Service; USGS 2014) on the global reserves as of 2014, a decade and half averaged production, and estimated availability in years, for these elements. Chlorine, for which no estimates are made, exists in the chloride form, and is abundantly available in soil, air, water, and rock salts, ranking 18th in abundance among all elements (Graedel and Keene 1996). The table further shows that with the exception of $\mathrm{B}$, the production of which remained relatively stable over the 10 -year period, the production of micronutrients has increased significantly over time, with $\mathrm{Ni}$ being the most exploited. Yet, it is suggested that relative to the total use of micronutrients in various industrial and chemical processes in the USA for which there is reliable data, application of micronutrients in agriculture represents only a tiny fraction, which, for $\mathrm{Zn}$, one of the most used agriculturally, is about $4 \%$ (Hignett and McClellan 1985). From our experience in the fertilizer realm, this trend has not improved much over time. There is, therefore, the concern that the agricultural demand for micronutrients will continue to be outpaced by demand from other sectors (Udo de Hais et al. 2012). More striking though is that collectively, the data in Table 1 suggest that the global availability of these micronutrients could become an issue of concern in the future; most have $<50$ years left. The estimated 
Table 1 Global resources, chemistry, and biology essentials of micronutrients at a glance

\begin{tabular}{|c|c|c|c|c|c|c|c|}
\hline \multirow[t]{2}{*}{ Element } & \multirow[t]{2}{*}{$\begin{array}{l}\text { Global reserves } \\
\text { (2014) (in } \\
\text { metric tons; } \\
\text { MT) }\end{array}$} & \multicolumn{3}{|c|}{$\begin{array}{l}\text { Global annual production trend in } \\
\text { metric tons (each listed year is } \\
\text { averaged from the two previous } \\
\text { years before it. For e.g., data for } \\
\text { year } 2000 \text { is the average of } 1998 \\
\text { and 1999) }\end{array}$} & \multirow[t]{2}{*}{$\begin{array}{l}\text { Availability } \\
\text { (years) }\end{array}$} & \multirow[t]{2}{*}{$\begin{array}{l}\text { Plant shoot } \\
\text { uptake } \\
\text { form }\end{array}$} & \multirow[t]{2}{*}{ Uptake mechanism } \\
\hline & & $\begin{array}{l}\text { Year } \\
2000\end{array}$ & $\begin{array}{l}\text { Year } \\
2010\end{array}$ & $\begin{array}{l}\text { Year } \\
2014\end{array}$ & & & \\
\hline $\begin{array}{l}\text { Iron }(\mathrm{Fe} \text {; as } \\
\text { iron ore) }\end{array}$ & 170 billion & 1006 & 2260 & 2940 & 82 & $\mathrm{Fe}^{2+}, \mathrm{FeO}^{\mathrm{c}}$ & $\begin{array}{l}\text { Reduction and transport by divalent cation } \\
\text { transporter for dicots and nongrass monocots; } \\
\text { chelation of trivalent Fe in grass monocots; } \\
\text { possible endocytosis }\end{array}$ \\
\hline $\begin{array}{l}\text { Manganese } \\
(\mathrm{Mn})\end{array}$ & 570,000 & 6,890 & 11,450 & 16,400 & 49 & $\mathrm{Mn}^{2+}, \mathrm{Mn}^{\mathrm{c}}$ & Divalent cation transporter; possible endocytosis \\
\hline Zinc $(\mathrm{Zn})$ & 230,000 & 7595 & 11,350 & 13,500 & 21 & $\mathrm{Zn}^{2+}, \mathrm{ZnO}^{\mathrm{c}}$ & Divalent cation transporter; possible endocytosis. \\
\hline Copper $(\mathrm{Cu})$ & 690,000 & 12,400 & 15,600 & 17,400 & 46 & $\begin{array}{l}\mathrm{Cu}^{+}, \mathrm{Cu}^{2+}, \\
\mathrm{CuO}^{\mathrm{c}}\end{array}$ & Divalent cation transporter; possible endocytosis. \\
\hline Boron (B) & 210,000 & 4420 & 4425 & 4660 & 47 & $\begin{array}{l}\text { Uncharged } \\
\text { boric } \\
\text { acid } \\
{[\mathrm{B}(\mathrm{O}-} \\
\left.\mathrm{H})_{3}\right]\end{array}$ & $\begin{array}{l}\text { Diffusion; channel transport; high-affinity B } \\
\text { transporter }\end{array}$ \\
\hline $\begin{array}{l}\text { Molybdenum } \\
\text { (Mo) }\end{array}$ & $11,000,000$ & 132,000 & 209,000 & 264,500 & 54 & $\begin{array}{l}\text { Molybdate } \\
\left(\mathrm{MoO}_{4}^{2}\right. \\
\quad)\end{array}$ & High-affinity $\mathrm{MoO}_{4}{ }^{2-}$ transporter; sulfate transporter \\
\hline Chlorine $(\mathrm{Cl})$ & No data & No data & No data & No data & $\begin{array}{l}\text { No data } \\
\quad \text { (highly } \\
\text { abundant } \\
\text { in nature) }\end{array}$ & $\begin{array}{l}\text { Chloride } \\
\qquad\left(\mathrm{Cl}^{-}\right)\end{array}$ & $\mathrm{Cl}^{-}$transporters \\
\hline Nickel (Ni) & $74,000,000$ & $1,140,000$ & $1,500,000$ & $2,355,000$ & 44 & $\mathrm{Ni}^{2+}$ & Diffusion; divalent metal transporters \\
\hline
\end{tabular}

Table synthesized from the US Geological Service (www.minerals.usgs.gov/minerals/pubs/mcs) and Bindraban et al. (2015)

${ }^{a}$ Amount economically extractable or produced at a given time

${ }^{\mathrm{b}}$ Estimated by dividing the global reserves (column 2) by the average of the averaged (column 2) yearly production

${ }^{\mathrm{c}}$ Recent studies on the environmental implications of nanotechnology indicate uptake of these elements in particulate forms (see references on nanoparticle studies in this review)

years of availability would, of course, depend on factors such as up- or downward changes in production levels, improvement in mining technologies that minimize waste, and discovery of new mines (see also, Chardon and Oenema 2013). Nevertheless, serious efforts need to be made now to sustain their use, especially for $\mathrm{Zn}$, if we are to maximize their benefits in crop production for much longer. This topic will be revisited at a later section.

\subsection{Micronutrient deficiencies in soil}

Although soils may contain significant amounts of micronutrients, their availability to plants could be regulated, under the influence of different edaphic and biological factors such as $\mathrm{pH}$, competing cations, anions, organic matter, soil geomorphology, soil parent materials, and soil microbiology.
Upon contact with soil, some micronutrients undergo rapid reaction with compounds such as phosphates and carbonates, to form chemical precipitates, or they may interact with clay colloids and other mineral complexes, rendering them unavailable to the crop (Allen 2002; Marschner 2012). Furthermore, similarities in the biological uptake mechanisms of micronutrients by plant roots (Table 1) also influence the ultimate plant bioavailability of specific micronutrients. Nevertheless, soil micronutrient availability could be modulated by changing the soil $\mathrm{pH}$, such as through liming with dolomite. Also, specific plants may scavenge the soil for micronutrients through adaptation strategies such as the elaboration of extensive root systems, and importantly, the excretion of exudates, including organic acids and phytosiderophores, to dissolve fixed minerals (White et al. 2013; Keuskamp et al. 2015). 
Micronutrient deficiency in soil is a global phenomenon, although to varying extents for the different micronutrients (Voortman and Bindraban 2015; Monreal et al. 2015). However, one commonality with micronutrients in different global agroecosystems is the fact that their deficiency in crops is compounded by a low crop use efficiency (i.e., low crop response per unit of micronutrient, relative to no micronutrient application), typically $<10 \%$, compared to between 20 and $80 \%$ for N, P, and K (Baligar et al. 2001). Also, in vast regions of the globe (for instance, in several countries of Africa and Asia), it is reported that majority of the arable land is affected by multiple micronutrient deficiencies (Voortman and Bindraban 2015; Monreal et al. 2015; Oliver and Gregory 2015). In these regions, the scenario is further complicated by the inadequate replenishment through fertilization of micronutrients biologically mined from the soil by plant roots, which has had negative agronomic consequences for crop productivity. For example, the use of NPK fertilizers in India for growing rice and wheat over many decades contributed to high crop yields but also resulted in crops extracting micronutrients from the soil to the extent that the bioavailability of micronutrients such as $\mathrm{Zn}$ has become so limited that it poses problems for $\mathrm{Zn}$ nutrition of humans (Cakmak 2009; Monreal et al. 2015). Not surprisingly, the application of micronutrients has been found to ameliorate micronutrient deficiency and, consequently, improve crop yield levels. Rietra et al. (2015) have summarized positive yield responses observed upon application of micronutrients to crops such as soybean (Glycine max), tobacco (Nicotiana sp.), wheat (Triticum aestivum L.), and cauliflower (Brassica oleracea) that had received one or all of the NPK nutrients. Much earlier, Katyal and Ponamperuma (1974) demonstrated that the addition of $\mathrm{Zn}$ increased rice (Oryza sativa) yield, which occurred whether NPK was present (by $77 \%$ ) or not (by $53 \%$ ). Kanwar and Youngdahl (1985) reported that the extent of the response of bean (Phaseolus vulgaris), maize (Zea mays), potato (Solanum tuberosum L.), sorghum (Sorghum bicolor), rice, and wheat to different micronutrients was micronutrient-specific, but that most crops responded highly to $\mathrm{Zn}$ than to $\mathrm{Fe}$, $\mathrm{Mn}$, and $\mathrm{Cu}$, in that order. Such historical observations of the positive effects of micronutrients have continued to be made. In currently ongoing studies, yield responses of $30 \%$ or more are being obtained in experimental and farm demonstration trials in several African countries (Vanlauwe et al. 2014; International Fertilizer Development Center [IFDC], unpublished data). Figure 1 shows growth patterns of maize in subplots of the same African field treated with NPK or NP $+\mathrm{S}+$ $\mathrm{Zn}+\mathrm{B}$, demonstrating the influence of micronutrients in crop performance. The increased yield obtained upon application of micronutrients in NPK-fertilized soils support the notion that the often observed nonresponsiveness to NPK fertilization of certain soils in Africa could, at least partially, be attributed to the inherent lack of micronutrients in these soils
(Vanlauwe et al. 2010; Voortman and Bindraban 2015). However, crop response to micronutrients in terms of yield stimulation is different than, and sometime not correlated with, response in terms of enhanced nutrient uptake into edible portions, which is important for humans consuming such crops.

\subsection{Soil micronutrients in relation to human health}

As previously indicated, human nutrition is either directly or indirectly plant-based through feeding on animals that feed on plants. As such, a micronutrient deficiency in food crops, due to its lack in soil, could translate to micronutrient deficiency in humans (White and Broadley 2009; Martínez-Ballesta et al. 2010; Joy et al. 2015; Oliver and Gregory 2015). In countries where staple foods consist mainly of cereals and tubers grown in nutrient-poor soils, human micronutrient deficiency, especially of $\mathrm{Zn}$, is widespread, representing a major cause of stunting and child death. Hence, micronutrient fertilization of crops (in other words, agronomic fortification), in addition to increasing crop yield for human consumption, may address crop nutritional quality and attendant micronutrient dietary concerns in human health (Cakmak 2009; White and Brown 2010; Joy et al. 2015).

There are of course alternatives to agronomic fortification for micronutrient supply to humans, including plant breeding and genetic engineering (biofortification), postharvest biofortification of food as done by the Food Industry, and consumption of micronutrient supplements. Indeed, there are strong and ongoing efforts by the HarvestPlus program on biofortification of different crops with $\mathrm{Fe}, \mathrm{Zn}$, and vitamin $\mathrm{A}$ in different countries (http://www.harvestplus.org/content/ crops). However, biofortification strategies are long term in nature because they usually require several painstaking stages (germplasm screening, varietal crossing, molecular makerassisted selection, and phenotyping of new crop breeds). In addition, the complex multigenetic steps involved in moving nutrients from the soil to the grains or edible leaves would have to be surmounted, to actually arrive at crops with enhanced micronutrient uptake and tissue transport ability (Waters and Sankaran 2011; Velu et al. 2014). Similarly, genetic engineering of crops requires highly technical skill sets, and the use of genetically modified crops is still an open debate in many countries. Depending on the plant, biofortification especially by genetic engineering could be confounded by the commonality in the uptake pathway of many of the micronutrients that leads to antagonistic nutrient interactions, or the co-uptake of toxic heavy metals such as $\mathrm{Cd}$ (Slamet-Loedin et al. 2015). As things currently stand, the success of any bio-based micronutrient fortification would depend to a large extent on the ready-availability of micronutrients in the soil at adequate amounts for plant uptake or of micronutrient products that can be used to fertilize the 
Fig. 1 Growth response of fieldgrown maize to NPK (left) and NP applied together with S, Zn, and B (right). Photo courtesy of J. Wendt, IFDC
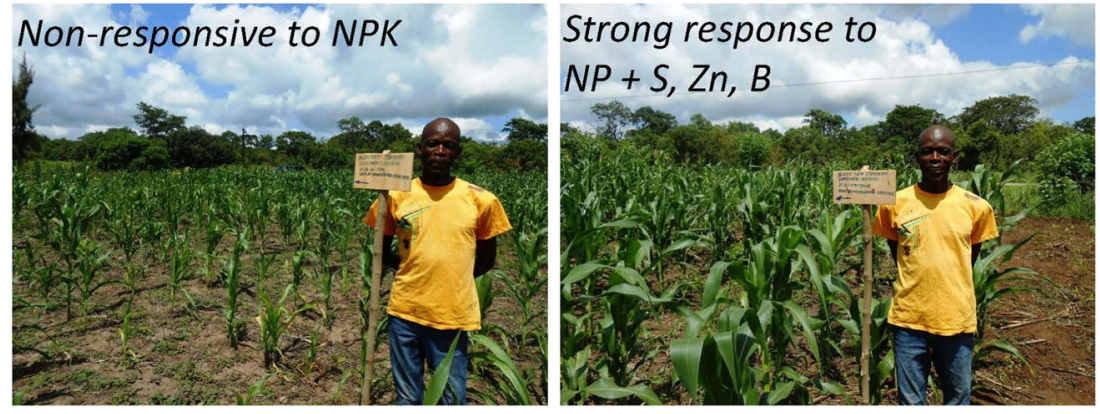

soil (Cakmak 2008). It would appear that only when these are ensured that the greatest genetic potential of the plant can be leveraged to maximize nutrient uptake into the plant.

In contrast to biofortification, micronutrient fertilization has been found to be capable of directly increasing the nutritional content of crops in the short term, such as for $\mathrm{Zn}$ (Cakmak 2008; Duffner et al. 2014; Velu et al. 2014) and even for Se (Broadley et al. 2006; Ros et al. 2014), as mentioned previously. Notably, the micronutrient contents of several crops, including grains (Garvin et al. 2006; Graham et al. 2007; Fan et al. 2008) and vegetables (Mayer 1997; Davis et al. 2004; White and Broadley 2005), have declined over the past decades, even as yield increased. The reason for this trend could be explained by two factors: (i) the use of highyielding crop varieties (Monasterio and Graham 2000) and (ii) the continuous mining of soil micronutrients by crops and nonreplenishment by fertilization, especially in poorer countries (Cakmak 2009; Jones et al. 2013). Regarding the first scenario, the increased crop biomass, grain yield, and/or harvest index (i.e., ratio of grain biomass to total biomass) often accompanying NPK application to high-yielding crop varieties would cause a dilution of the micronutrient concentrations in the aerial plant parts, thus reducing the amount ultimately translocated to edible portions of the crop, especially grains (Garvin et al. 2006; Fan et al. 2008). The positive results obtained in several countries, particularly in Turkey, where the deployment of $\mathrm{Zn}$ fertilization, and experimenting with timing and routes of application in wheat and rice, have resulted in dramatic simultaneous outcomes for crop yield and nutritional quality, illustrate the power of $\mathrm{Zn}$ micronutrient fertilization to address the widespread $\mathrm{Zn}$ deficiency in soils and, consequently, in humans (Cakmak 2008; Cakmak et al. 2010; Phattarakul et al. 2012; Zou et al. 2012). While these findings with $\mathrm{Zn}$ indicate that micronutrient fertilizers may be critical in fighting hidden hunger, they require continuous empirical evidence such as through efficacy trials with all micronutrients and most staple crops. Moreover, with the continuous incursion of seed companies marketing improved crop seeds in emerging agricultures in developing countries, it becomes even more imperative to support the use of such highyielding crop varieties with micronutrient inputs, in order to enhance their contents in the plant.

\subsection{Micronutrients and the ecosystem}

A major reason for the low use efficiency of NPK fertilizers by plants is the high losses via leaching, fixation, and/or volatilization of these nutrients. However, the fact that crop yields can increase with the addition of micronutrients, sometimes even at decreased amounts of NPK fertilization (IFDC, ongoing studies), suggests that increased use efficiency of the NPK and, hence, reduced nutrient losses to the environment are possible. In addition, the presence of nutrients may enhance water use efficiency under water-deficient conditions that reduce crop performance (Molden et al. 2010). For example, Movahhedy-Dehnavy et al. (2009) reported in safflower (Carthamus tinctorius L.) that a foliar application of $\mathrm{Zn}$ and Mn improved yield and quality of seeds under water stress. Similarly, enhanced water use efficiency of rice was demonstrated under saline condition, upon foliar application of $\mathrm{Zn}$ (Ashraf et al. 2014), presumably through $\mathrm{Zn}$ stimulation of root mechanisms that enhanced nutrient and water uptake. Another added ecological benefit of micronutrients is seen in their role in suppressing plant diseases as will be discussed in more detail subsequently. Collectively, these co-benefits can make an important contribution to climate-smart agriculture, enhancing the sustainability and resiliency of agricultural production systems.

The above-described positive impacts of micronutrients have been recorded across soils and crops, indicating the generic nature of micronutrient limitation and the need to incorporate them in novel fertilizers that are accessible to resourcepoor and rich farmers alike, for deliberately enhancing crop productivity and quality. However, the use of micronutrients, most of which are heavy metals, could bring about ecological challenges when administered at certain high levels. Representative phytotoxicology studies with micronutrients in controlled greenhouse pot microcosms show, for example, that $\mathrm{Ni}, \mathrm{Cu}$, and $\mathrm{Zn}$, respectively, could be toxic to different food/feed crop species at certain high concentrations: $40 \mathrm{mg}$ $\mathrm{Ni} \mathrm{kg}{ }^{-1}\left(\approx 80 \mathrm{~kg} \mathrm{ha}^{-1}\right)$ for spinach (Spinacia oleracea), zucchini (Cucurbita pepo), and bean (Matraszek et al. 2002); $120 \mathrm{mg} \mathrm{Cu} \mathrm{l}^{-1}\left(\approx 240 \mathrm{~kg} \mathrm{ha}^{-1}\right.$ ) for wheat (Paschke and Redente 2002); >369 $\mathrm{mg} \mathrm{Zn}^{-1}$ (>738 kg ha ${ }^{-1}$ ) for flax (Linum usitatissimum) (Paschke et al. 2006); and $250 \mathrm{mg} \mathrm{Zn}$ 
$\mathrm{kg}^{-1}\left(500 \mathrm{~kg} \mathrm{ha}^{-1}\right)$ for alfalfa (Medicago sativa) (Bandyopadhyay et al. 2015). However, these levels are unrealistic in normal agricultural soils for micronutrients. Fortunately, reports of soil inherent micronutrient toxicity in most agricultural fields are rare, due to their reduced level of bioavailability to plants. Nevertheless, misuse or misapplication during deliberate agronomic use of micronutrients to enhance their levels in crops for human consumption could lead to toxicity outcomes, given that they could be toxic at certain elevated concentrations. Furthermore, application of contaminated inputs could serve as other routes by which micronutrient toxicity may indirectly occur (Alloway and Jackson 1991; Wuana and Okieimen 2011). Such inputs include irrigation water and pesticides and heavy metal-containing sewage sludge used as biosolid amendments in soil. Also, crop production in saline/sodic soil (in the case of $\mathrm{B}$ and $\mathrm{Cl}$ ), on land proximal to sites polluted with heavy metals from natural (e.g., serpentine soils with high Ni concentrations) or anthropogenic events, and on acidic soils (for Mn) could lead to the occurrence of micronutrient toxicity.

Despite the contradiction of micronutrients in being both beneficial and detrimental to crops, we opine that micronutrient agronomic fortification could offer great potential to simultaneously alleviate some of the challenges militating against the quantitative and qualitative (nutritional and healthy) production of crops, especially in less agriculturally developed areas where micronutrient use has been limited and, in many cases, nonexistent. Here, we visualize the potential of adopting micronutrients as an all-in-one input for simultaneously enhancing crop yield, increasing the nutrient contents of crops, suppressing crop diseases and abiotic stressors, and stimulating biomass production, with the ultimate aims of increasing farming income and contributing to improved human nutrition.

\section{Roles of micronutrients in crops}

Although the physiological role of micronutrients in plants has been described extensively in the literature (see for, e.g., Datnoff et al. 2007; Marschner 2012), we feel that it is beneficial to highlight specific aspects of micronutrient physiological relations with plants and with plant diseases and abiotic stressors, as these have direct agronomic ramifications for crop yield and nutritional quality. Moreover, it is our opinion that future fertilizer innovations aimed at improving nutrient uptake should emphasize the biological processes that could make or mar the success of any fertilizer application, so that the chemists and engineers, who by training are responsible for fertilizer design and production, can better appreciate the need for suitably packaged fertilizers from a biological perspective (Bindraban et al. 2015).

\subsection{Physiological roles and roles in abiotic and biotic stress mitigation}

There is no doubt that without micronutrients, many of the processes that drive plant metabolism of $\mathrm{N}, \mathrm{P}, \mathrm{K}, \mathrm{Mg}, \mathrm{Ca}$, and $\mathrm{S}$, as well as crop responses to ecological perturbations, would not be optimally functional. $\mathrm{Fe}, \mathrm{Cu}, \mathrm{Mn}$, and $\mathrm{Cl}$ are involved in different aspects of plant photosynthesis, as cofactors for different metabolic processes. Dependent on the enzyme, $\mathrm{Fe}, \mathrm{Mn}, \mathrm{Zn}, \mathrm{Cu}, \mathrm{Ni}, \mathrm{Mo}$, and $\mathrm{Cl}$ all participate in the functioning of different enzymes, including DNA/RNA polymerases, N-metabolizing enzymes, superoxide dismutases, catalases, dehydrogenases, oxidases, ATPases, and numerous other enzymes involved in redox processes (Broadley et al. 2012). This cofactor role of micronutrients is crucial for enzyme and nonenzyme activities in plant metabolism under different environmental conditions (Table 2). For instance, $\mathrm{Zn}$ specifically plays a role in the enzymatic processes involved in the biosynthesis of the plant growth regulator, auxin (Hossain et al. 1997; Fageria 2002). This is an important function given the role of auxins in enhancing root growth, with agronomic consequences in terms of allowing the plant greater ability to access nutrients and water. $\mathrm{Ni}$ is involved with urease enzyme in the $\mathrm{N}$ metabolism of plants by converting urea to ammonia. Prior studies with soybean showed that a Ni deficiency-induced regulation of the activity of urease negatively impacted $\mathrm{N}$ metabolism in the plant, leading to urea accumulation and necrosis of shoot (Polaccao et al. 1999; Sirko and Brodzik 2000). Mo is required for N fixation by both symbiotic and free-living N-fixing bacteria, being a component of the nitrogenase enzyme system (Barron et al. 2009), and therefore, essential for legume cropping systems, and in efforts to enhance biological $\mathrm{N}$-fixation to supplement mineral $\mathrm{N}$-fertilization.

In terms of abiotic stress mitigation, $\mathrm{Zn}$ has also been shown to modulate the activity of enzymes, such as the membrane-bound NADPH oxidase (Cakmak 2000) involved in the homeostasis of reactive oxygen species that, at relevant levels, mediate important cellular functions like host defense and signaling during drought or other abiotic stresses (Golldack et al. 2014). In agronomic studies conducted under drought conditions with adequate $\mathrm{N}$ and $\mathrm{P}\left(70: 70 \mathrm{~kg} \mathrm{ha}^{-1}\right)$ supply, Bagci et al. (2007) demonstrated that while inadequate water supply under rain-fed systems could decrease average wheat grain yield by as much as $25 \%$, the addition of $\mathrm{Zn}$ (23 $\mathrm{kg} \mathrm{ha}^{-1}$ as a foliar application) increased wheat yield by $16 \%$. Thus, $\mathrm{Zn}$ application lowered loss in yield due to water shortage from 25 to $13 \%$. $\mathrm{Cu}$ is specifically essential for carbohydrate metabolism and required for the synthesis of lignin needed for cell wall strengthening (Yruela 2009; Ryan et al. 2013a, b). The latter role could have implications for the survival of plants under the abiotic stresses of wilting, windiness, or rainstorm conditions where plant rigidity is 
Table 2 Summary of the modes of action, ecophysiological indicators addressed by micronutrients, and their agronomic outcomes

\begin{tabular}{|c|c|c|c|c|}
\hline \multirow[t]{2}{*}{ Nutrient } & \multicolumn{2}{|c|}{ Mode of action } & \multirow{2}{*}{$\begin{array}{l}\text { Main ecological indicators } \\
\text { addressed }\end{array}$} & \multirow{2}{*}{$\begin{array}{l}\text { Agronomic outcomes of } \\
\text { adequate supply }\end{array}$} \\
\hline & $\begin{array}{l}\text { Involvement } \\
\text { in } \\
\text { enzymatic } \\
\text { activity }\end{array}$ & $\begin{array}{l}\text { Involvement in } \\
\text { nonenzymatic } \\
\text { activity }\end{array}$ & & \\
\hline $\mathrm{Fe}$ & $\checkmark$ & $\begin{array}{l}\checkmark \text { (leghemoglobin, } \\
\text { ferritin, } \\
\text { phytosideropho- } \\
\text { res) }\end{array}$ & $\begin{array}{l}\text { Pathogens, biocontrol } \\
\text { bacterial interactions, } \\
\text { deficiency symptoms, } \\
\text { photosynthesis, } \\
\text { rhizosphere processes }\end{array}$ & $\begin{array}{l}\text { Improvement in seed quality, } \\
\text { support of vigorous } \\
\text { seeding emergence and } \\
\text { seedling growth, crop } \\
\text { resiliency to diseases, } \\
\text { stimulation of yield, and } \\
\text { enhancement of Fe } \\
\text { content }\end{array}$ \\
\hline $\mathrm{Zn}$ & $\checkmark$ & $\checkmark$ (ribosomes) & $\begin{array}{l}\text { Pathogens, biocontrol } \\
\text { bacterial interaction, } \\
\text { drought, deficiency } \\
\text { symptoms, rhizosphere } \\
\text { processes }\end{array}$ & $\begin{array}{l}\text { Improvement in seed quality, } \\
\text { support of vigorous } \\
\text { seedling emergence and } \\
\text { seedling growth, root } \\
\text { development, crop } \\
\text { resiliency to diseases and } \\
\text { abiotic stressors, } \\
\text { stimulation of yield, and } \\
\text { enhancement of } \mathrm{Zn} \\
\text { content }\end{array}$ \\
\hline $\mathrm{Cu}$ & $\checkmark$ & & $\begin{array}{l}\text { Pathogens, deficiency } \\
\text { symptoms, } \\
\text { photosynthesis, tolerance } \\
\text { to wilting and logging }\end{array}$ & $\begin{array}{l}\text { Improvement in seed quality, } \\
\text { support of vigorous } \\
\text { seedling emergence and } \\
\text { seedling growth, crop } \\
\text { resiliency to pathogens, } \\
\text { pests and abiotic stressors, } \\
\text { stimulation of yield, and } \\
\text { enhancement of } \mathrm{Cu} \\
\text { content }\end{array}$ \\
\hline $\mathrm{Mn}$ & $\checkmark$ & $\begin{array}{l}\checkmark(\mathrm{CHO} \text { and lipid } \\
\text { metabolism })\end{array}$ & $\begin{array}{l}\text { Pathogens, deficiency } \\
\text { symptoms, } \\
\text { photosynthesis }\end{array}$ & $\begin{array}{l}\text { Improvement in seed quality, } \\
\text { support of vigorous } \\
\text { seedling emergence and } \\
\text { seedling growth, crop } \\
\text { resiliency to pathogens } \\
\text { and abiotic stressors, } \\
\text { stimulation of yield, and } \\
\text { enhancement of Mn } \\
\text { content }\end{array}$ \\
\hline $\mathrm{Ni}$ & $\checkmark$ & & $\begin{array}{l}\text { Pathogens, deficiency } \\
\text { symptoms, nitrogen } \\
\text { metabolism }\end{array}$ & $\begin{array}{l}\text { Improvement in seed quality, } \\
\text { support of vigorous } \\
\text { seedling emergence and } \\
\text { seedling growth, crop } \\
\text { resiliency to pathogens } \\
\text { and pests, stimulation of } \mathrm{N} \\
\text { use efficiency, stimulation } \\
\text { of yield, and enhancement } \\
\text { of Ni content }\end{array}$ \\
\hline Mo & $\checkmark$ & & $\begin{array}{l}\text { Pathogens, } \mathrm{N} \text {-fixation by } \\
\text { microbes in legumes }\end{array}$ & $\begin{array}{l}\text { Improvement in seed quality, } \\
\text { support of vigorous } \\
\text { seedling emergence and } \\
\text { seedling growth, crop } \\
\text { resiliency to pathogens, } \\
\text { stimulation of } \mathrm{N} \text { use } \\
\text { efficiency, stimulation of } \\
\text { yield, and enhancement of } \\
\text { Mo content }\end{array}$ \\
\hline
\end{tabular}


Table 2 (continued)

\begin{tabular}{|c|c|c|c|c|}
\hline \multirow[t]{2}{*}{ Nutrient } & \multicolumn{2}{|c|}{ Mode of action } & \multirow{2}{*}{$\begin{array}{l}\text { Main ecological indicators } \\
\text { addressed }\end{array}$} & \multirow{2}{*}{$\begin{array}{l}\text { Agronomic outcomes of } \\
\text { adequate supply }\end{array}$} \\
\hline & $\begin{array}{l}\text { Involvement } \\
\text { in } \\
\text { enzymatic } \\
\text { activity }\end{array}$ & $\begin{array}{l}\text { Involvement in } \\
\text { nonenzymatic } \\
\text { activity }\end{array}$ & & \\
\hline B & & $\checkmark$ & $\begin{array}{l}\text { Pathogens, deficiency } \\
\text { symptoms, tolerance to } \\
\text { logging }\end{array}$ & $\begin{array}{l}\text { Improvement in seed quality, } \\
\text { support of vigorous } \\
\text { seedling emergence and } \\
\text { seedling growth, crop } \\
\text { resiliency to pests, } \\
\text { pathogens and abiotic } \\
\text { stressors, stimulation of } \\
\text { yield, and enhancement of } \\
\text { B content }\end{array}$ \\
\hline $\mathrm{Cl}$ & $\checkmark$ & $\checkmark$ & $\begin{array}{l}\text { Pathogens, resistance to } \\
\text { wilting, photosynthesis, } \\
\text { rhizosphere processes }\end{array}$ & $\begin{array}{l}\text { Improvement in seed quality, } \\
\text { crop resiliency to pests, } \\
\text { pathogens and abiotic } \\
\text { stressors, stimulation of } \\
\text { yield }\end{array}$ \\
\hline
\end{tabular}

important. As the borate ion, B is involved in cell wall functioning by facilitating the cross-linking of pectic polysaccharides. It also plays a role in the structural integrity of the cytoskeleton (Miwa and Fujiwara 2010). Chloride plays a role in stomatal regulation; hence, its deficiency results in wilting of the leaf and death of the plant (Broadley et al. 2012).

Regarding biotic stress, micronutrients may influence plant response to disease either indirectly, through affecting the pathogen's survivability in the crop rhizosphere or in planta, or directly, through evoking a variety of physiological responses in the plant during pathogen attack. The role of Fe in crop disease suppression appears to be mainly indirect, through the interactions of root-associated beneficial microbes (so-called biocontrol agents) with disease-causing soil microbes. Here, siderophores, metal chelators produced by beneficial microbes in response to Fe scarcity, play a role in depriving pathogens of $\mathrm{Fe}$, as well as in availing plants with Fe and other metallic micronutrients (Kloepper et al. 1980; Lim and Kim 1997; Vansuyt et al. 2007; Dimkpa et al. 2009, 2015a). This role is the basis for the use of siderophoreproducing bacteria, or siderophores extracted from bacteria, as biofertilizers to supply Fe to plants (Fernandez et al. 2005; Radzki et al. 2013). In contrast to Fe, Zn may act both directly and indirectly in plant-pathogen systems. Directly, it may act as signals for the cellular activities of proteins involved in disease resistance in cereals (Shirasu et al. 1999; Datnoff et al. 2007). Indirectly, Zn may act by influencing pathogen growth via the stimulation of the activity of biocontrol bacteria producing antimicrobial metabolites such as salicylic acid, siderophores, and the antibiotic, 2,4-diacetylphloroglucinol (Duffy and Defago 1999; Dimkpa et al. 2012a, 2015a), causing membrane damage, hyphal structural damage, oxidative stress, or reduction of siderophore production (He et al. 2012;
Dimkpa et al. 2013a, b; Dimkpa 2014; Zabrieske et al. 2015). Notably, the acidification of the environmental to a $\mathrm{pH}$ range that might be nonoptimal for pathogen growth seems to be another mechanism by which $\mathrm{Zn}$ may indirectly play a role in soil-borne crop disease control (Dimkpa et al. 2013a, b). It is plausible that a micronutrient mechanism that acidifies the rhizosphere could enhance plant uptake of such micronutrients. Not surprisingly, disease suppression by $\mathrm{Zn}$ and $\mathrm{Mn}$, for example, has been correlated with increased $\mathrm{Zn}$ and $\mathrm{Mn}$ contents in the crop or the crop rhizosphere (Huber and Wilhelm 1988; Sparrow and Graham 1988; Wilhelm et al. 1988; Grewal et al. 1996). Similarly, depending on the micronutrient, $\mathrm{Cu}, \mathrm{Ni}, \mathrm{Mn}, \mathrm{Mo}$, and $\mathrm{B}$ all have indirect microbicidal as well as direct effects on crops response to diseases. Indeed, $\mathrm{Cu}$ and $\mathrm{Ni}$ have historically been in use as crop protection products due to their high toxicity to microbes. However, the systemic, nonpoint source effects observed in plants upon application of micronutrients suggest that, in addition to pathogen toxicity, they might also directly be involved in physiological processes that confer plant resistance to diseases. Such processes include stimulating the production of antioxidants and other pathogen inhibitory compounds, influencing lignin and suberin biosynthesis to toughen cell walls and reduce pathogen infiltration, and modulating $\mathrm{N}$ metabolism in the plant (Huber and Wilhelm 1988; Römheld and Marschner 1991; Boyd et al. 1994; Bai et al. 2006; Evans et al. 2007; Stangoulis and Graham 2007; Taran et al. 2014; Servin et al. 2015a). Notably, B's involvement in cell wall regulation is related to the modulation of $\mathrm{Ca}$ balance in the cell wall, helping in the formation of calcium pectate that confer rigidity to the plant (Stangoulis and Graham 2007), which otherwise would be more easily weakened by disease or drought stress. 
Therefore, given that all micronutrients can contribute to disease suppression (Table 2), it seems plausible to suggest that there is a possibility for reducing the agricultural input of other types of crop microbicides, under a well-reasoned and integrated micronutrient fertilization regime. Clearly, the disturbance of plant physiological processes due to the deficiency of one or more micronutrients could result in poor seed and root development, reduced shoot development, reduced tolerance to biotic and abiotic environmental stresses, and ultimately, lowered yield, or even death of the plant. Fortunately, by improving the supply of micronutrients to plants in a "balanced" fertilizer regime, a slate of additional ecological benefits is derivable. Such benefits include the mitigation of the adverse effects of drought and pests on crops, necessary for crop adaptation to changing climate, and have the potential to moderate ecological pressures on crops (Ramegowda and Senthil-Kumar 2015 and references therein). In Fig. 2, we present a hypothetical scheme to further illustrate the role micronutrients can play in bridging yield gaps under unfavorable environmental conditions of biotic and/or abiotic stress.

\subsection{Role of micronutrients in crop nutritional quality}

Increasing the contents of micronutrients in crops is the aim of any fortification program. Hence, the addition of a

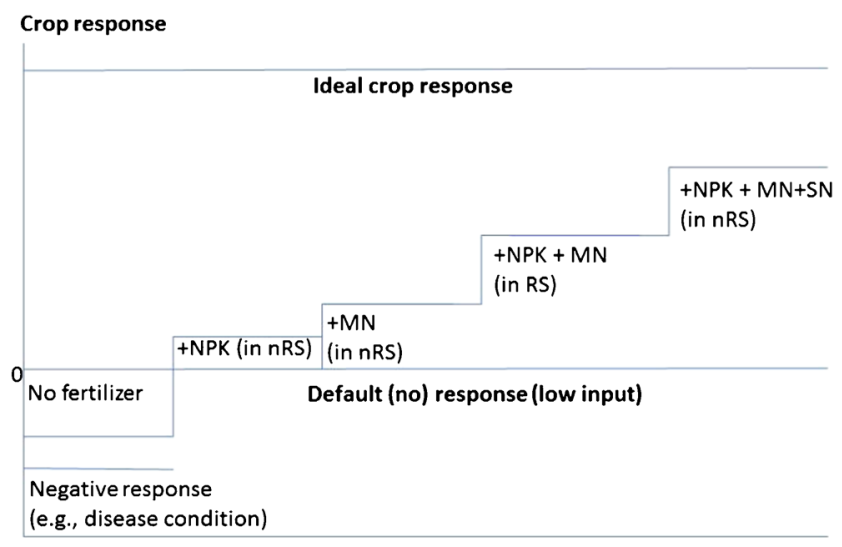

Treatment

Fig. 2 Schematic illustration of the potential influence of micronutrients (MN) on crop response (e.g., yield). Ideally, the expectation for crop production is to attain the highest possible response. However, maximum response is negated under different conditions such as abiotic (e.g., water deficit) and biotic (e.g., disease) stressors and crop genetic potential (e.g., low-yielding crop varieties). Similarly, yield is stagnated in the absence of nutrients from mineral or organic fertilizers. However, in nonresponsive (nRS) soils, addition of NPK alone may not enhance yield dramatically, while addition of micronutrients alone could elicit a significant yield response. Combined treatment with NPK and micronutrients boost yield very significantly. In this latter scenario, micronutrients, as active components of many important enzymes, increase the plant's ability to tolerate or resist environmental stressors. With NPK, micronutrients, secondary nutrients ( $\mathrm{SNs}$; $\mathrm{Ca}, \mathrm{Mg}$, and $\mathrm{S}$ ), and other favorable environmental and management conditions being present, yield can be pushed further in $\mathrm{nRS}$ micronutrient to cropped soils typically leads to an increase in its content in aerial plant tissues (Table 3). Thus, under the deficiency of specific micronutrients, their addition could bode well for the plant in terms of content improvement and, hence, their physiological role in the plant. However, a broader look at the interaction of micronutrients and crops has shown contradictory outcomes for the crop's overall nutritional quality when plants are administered with specific micronutrients. It is increasingly being observed in many studies that the addition of a micronutrient at certain levels influences the content of other nutrients in the crop (see for example, Kumar et al. 2009; Dimkpa et al. 2015a, b; Rietra et al. 2015). The information in Table 3, while by no means exhaustive, indicates that the addition of specific micronutrients could positively modulate the uptake of other micronutrients, to improve the overall nutritional status of the crop, beyond that of the added nutrient. However, as also shown in Table 3, in other instances, upon the addition of a specific micronutrient, the levels of other micronutrients are reduced, suggesting a negative uptake interaction between such micronutrients. As discussed in more detail in a subsequent section, such negative outcome in the overall micronutrient levels of plants upon the addition of a specific micronutrient could be due to competition for uptake that occurs among micronutrients, which becomes heightened with an imbalance in the soil proportions of the applied versus nonapplied but competing nutrients. Therefore, agronomic fortification with micronutrients should be an intervention in situations where specific micronutrients have been determined to be limiting for crop productivity, as well as for the health and well-being of animals and humans whose primary source of food includes such crops (Joy et al. 2014; Kumssa et al. 2015). However, achieving this would require prior crop- and soil-specific evaluations, to elucidate to what extent the micronutrient to be intervened in affects the nutritional levels of other micronutrients, by systematically determining nutrient ratios and antagonistic uptake interactions among the micronutrients, and between micronutrients and macronutrients. This will preclude the co-application of antagonistic micronutrients in fertilizer regimes while ensuring more plant-specific and balanced micronutrient ratios in fertilizer formulations (see Rietra et al. 2015). It is also noteworthy to caution here that although the agronomic fortification of crops with certain micronutrients ( $\mathrm{Fe}$ and $\mathrm{Zn}$ ) may be successful, their subsequent bioavailability to humans upon consumption of such crops may be impeded by the presence of antinutritional factors, such as phytate, which form insoluble complexes with these micronutrients.

In addition to enhancing crop nutritional quality, micronutrients, when efficiently translocated to seeds, could enhance seed vitality that then allows for good seed emergence and vigorous seedling growth (Welch and Graham 2002; Nestel et al. 2006; Velu et al. 2014). In this regard, 


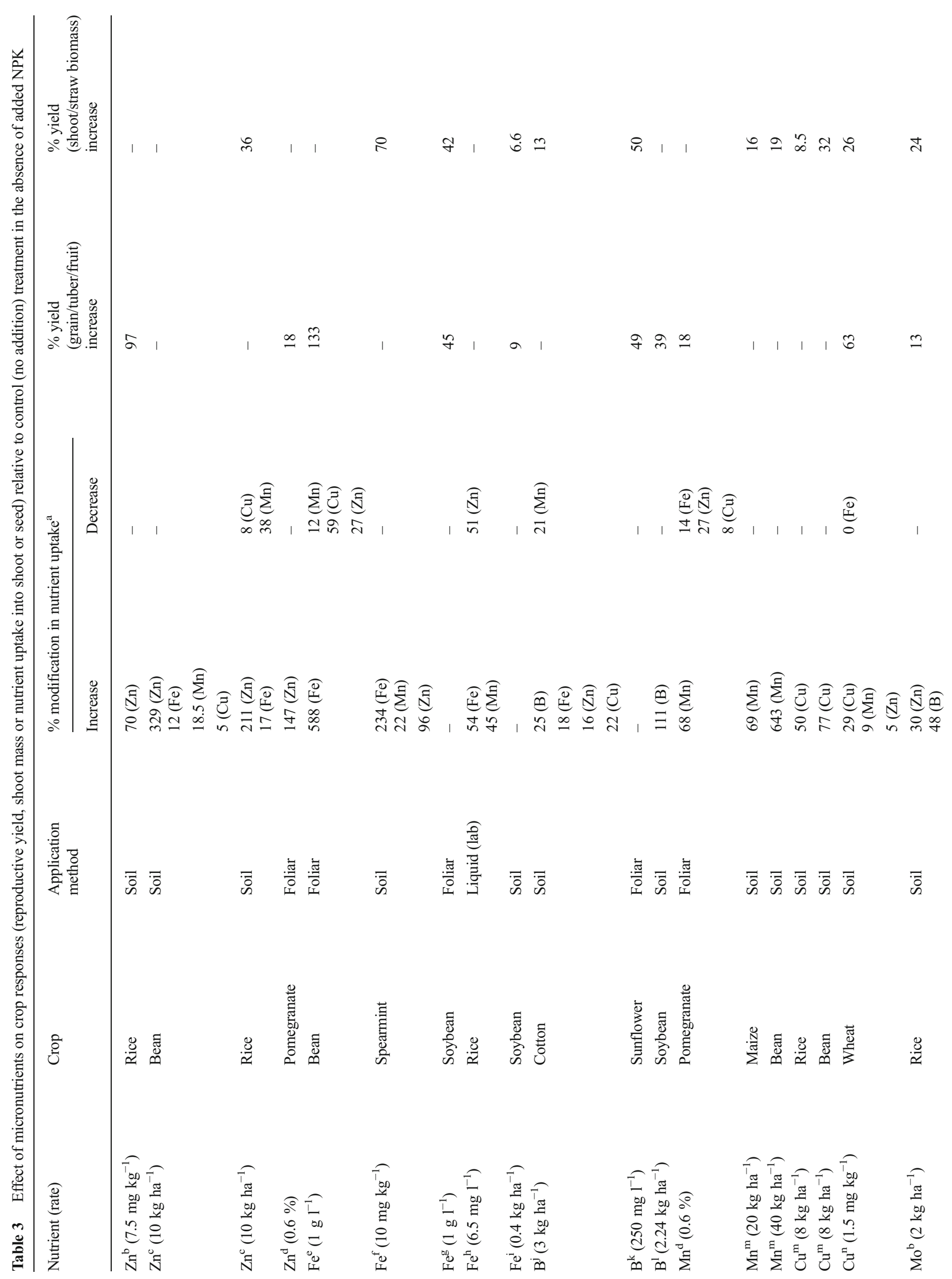




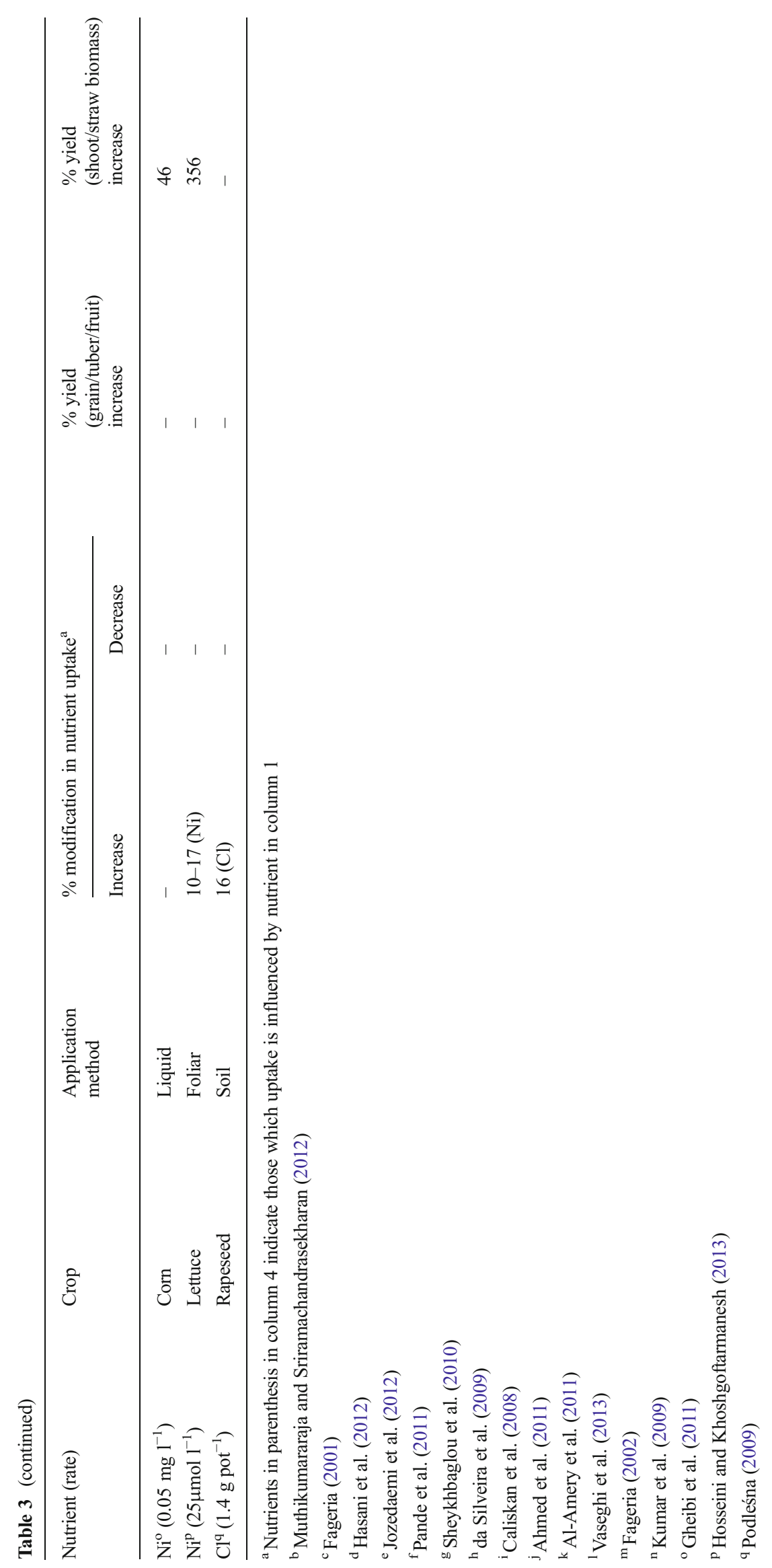


Brodrick et al. (1995), as well as Eggert and von Wirén (2013), demonstrated the relationship between nutrients - including micronutrients - and seed germination and production of good quality crops. Thus, guaranteeing good crop performance begins with the selection of quality seeds, for which adequate micronutrient content could play an important role (Bindraban et al. 2015). In this case, disease-free (an indicator of seed quality) seeds, as shown in the previous section, could come from plants correlated with increased micronutrient content.

\subsection{Agronomic role (i): enhancement of biomass production and yield}

As a likely consequence of their enhanced uptake, micronutrients can make significant contributions in enhancing crop growth and yield, especially under conditions of low soil nutritional endowment. Data in Table 3 indicate that micronutrients' ability to enhance yield is observed in both individual (see footnote in Table 3 legend) and mixed (e.g., Yaseen et al. 2013; Vanlauwe et al. 2014) nutrient applications. We speculate that the lack of micronutrient use in many agroecosystems, due in part to poor awareness regarding their role in crop development, contributes to their nonroutine application in such farming systems. Such lack of awareness was discussed in detail for the Middle East and West Asia by Ryan et al. (2013a, b)), who argued that in such agroecosystems, micronutrients' significance will become more apparent in the future, as the lack of other contributors to crop production such as improved crop varieties, irrigation, and proper crop management techniques is addressed.

As previously noted, exacerbating the current scenario could be the continuous mining of micronutrients from soil by plants, which consequently limits the benefits from NPK use. The collective annual removal of micronutrients in the soil by crops could range between 0.01 and $4.9 \mathrm{~kg} \mathrm{ha}^{-1}$, dependent on the micronutrients and crop (Rietra et al. 2015). For example, Mallarino et al. (2011) demonstrated in an Iowan soil that for a grain yield of about $4.8 \mathrm{tha}^{-1}$, soybean could remove between $0.09-0.23 \mathrm{~kg} \mathrm{ha}^{-1}, 0.03-0.07 \mathrm{~kg} \mathrm{ha}^{-1}$, and $0.05-0.08 \mathrm{~kg} \mathrm{ha}^{-1}$ of $\mathrm{Zn}, \mathrm{Mn}$, and $\mathrm{B}$, respectively, from the soil. Thus, with most crops requiring between 0.1 and $100 \mathrm{mg} \mathrm{kg}^{-1}$ of each of the micronutrients for normal growth (Marschner 2012), and with mean levels of $<1$ to $>90 \mathrm{mg} \mathrm{kg}^{-1}$ of these nutrients present in DTPA-extractible form, dependent on soil (McKenzie 2001; Samourgiannidis and Matsi 2013; Sobral et al. 2013), a normal healthy plant would not be able to meet the supply of all of its micronutrient requirements from the soil. Using these values, by a rough estimate, a crop would be deficit of micronutrients by $11 \%$ (difference between the amount present for uptake [upper limit; $90 \mathrm{mg} \mathrm{kg}^{-1}$ ] and the amount needed for normal growth [upper limit; $\left.100 \mathrm{mg} \mathrm{kg}^{-1}\right]$ ). Thus, the continuous mining of micronutrients from soils has serious ramifications for crop growth in agroecosystems where micronutrient fertilization is not a cultural farming practice.

Also noticeable from Table 3 is the fact that the positive responses to micronutrient treatment occurred in the absence of added NPK, demonstrating the power of micronutrients to influence crop responses on their own. But what does application route, soil or foliar, indicate in the plant responses? It is evident that the modulation of plant responses by micronutrients can be observed regardless of the application route. A number of studies have comparatively investigated plant responses to soil versus foliar micronutrient application. For example, Pestana et al. (2012) indicated that strawberry plants had more access to Fe when applied via root than via foliar. However, compared to the non-Fe-treated plants, the root levels of $\mathrm{Cu}, \mathrm{Zn}$, and $\mathrm{Mn}$ were more reduced when $\mathrm{Fe}$ was applied in the root, than in the leaves. No such differences were observed in the shoot levels of these nutrients, suggesting that the amount of Fe translocable from the root to shoot may be enough to match the Fe absorbed via leaves, without showing a suppression of the uptake and translocation of $\mathrm{Cu}, \mathrm{Mn}$, and $\mathrm{Zn}$. In other studies, Alidoust and Isoda (2013) reported more positive responses (e.g., increased photosynthesis) to foliar, than to root-applied Fe in soybean. This contrasts with the study of Rodriguez-Lucena et al. (2010) in a hydroponic system, where no foliar versus root differences were found in soybean, dependent on Fe chelate type. A different study by Wang et al. (2012a, b)) reported increased translocation of $\mathrm{Zn}$ to corn and wheat grains from foliar treatment than from soil $\mathrm{Zn}$ application. In contrast to these results, soil application resulted in greater corn grain yield and $\mathrm{Zn}$ uptake than foliar application (Puga et al. 2013), while side dressing (application at the side of the roots 4 weeks after sowing) of $\mathrm{Zn}, \mathrm{Mn}, \mathrm{Fe}, \mathrm{Cu}$, and $\mathrm{B}$ was more influential than soil and foliar applications for growth and yield in wheat (Nadim et al. 2012). These contradictions point to the plausibility that crop responses to different micronutrient application routes seem to be specie, cultivar, micronutrient, or soil dependent. Concerning Zn specifically, Joy et al. (2015), by metadata analysis studies of published literature, concluded that foliar application is more efficient than soil application in terms of delivering $\mathrm{Zn}$ into rice, maize, and wheat grains. Therefore, if application by the foliar route has such promise for agronomic fortification with micronutrients, whereas application through the soil can be fraught with reduced uptake efficiency due to loss of micronutrients associated with the vagaries of different soil chemistries, then foliar application of specific micronutrients in fertilizer regimes should become more routine, all other factors such as costs of equipment and training, where needed, being taken into consideration. Nevertheless, routinely adopting foliar application should be mainly in cases where benefits over soil application have been established. As would be shown subsequently, the physiological processes 
involved in the uptake/transport of most of the micronutrients via soil versus foliar present overlaps that could be exploited to establish complementary fertilizer application strategies for more potentially efficient agronomic fortification. That being said, given the paucity of soil versus foliar comparative data, more systematic studies would be required to compare these application methods under similar experimental conditions.

\subsection{Agronomic role (ii): enhancement of the efficiency of NPK}

Although macronutrients (mainly NPK) are the major drivers for increased crop productivity, there is ample evidence that their addition to the so-called nonresponsive soils may engender only minor growth/yield increases, if any, compared to no NPK addition (Vanlauwe et al. 2010; see also Fig. 1). In contrast, in nonresponsive soils, the yield-enhancing value of micronutrients comes to the fore. For example, Vanlauwe et al. (2014) reported that the omission of $\mathrm{Zn}\left(3 \mathrm{~kg} \mathrm{ha}^{-1}\right)$, B $\left(1 \mathrm{~kg} \mathrm{ha}^{-1}\right)$, and $\mathrm{Cu}\left(0.25 \mathrm{~kg} \mathrm{ha}^{-1}\right)$ from a field maize (Z. mays) fertilization regime $(\mathrm{N}, \mathrm{P}, \mathrm{K}, \mathrm{Mg}, \mathrm{Ca}, \mathrm{S}, \mathrm{Zn}, \mathrm{B}, \mathrm{Cu})$ could lead to yield reductions of 19,31 , and $31 \%$, respectively. In the same study, Vanlauwe et al. (2014) also reported increases of between 20 and $71 \%$ upon treatment of different field crops with different combinations of micro and secondary nutrients. Unfortunately, there are no data as to whether these yield increases correlated with micronutrient uptake in these studies. However, in Table 4, we present additional examples of nutrient uptake and yield data from studies where the application of specific micronutrients increased yield and/or nutrient content above the levels obtained when NPK (or other macronutrients) alone are added. Although such data are not adequately available for some of the micronutrients, the findings collectively reveal the relative influence of micronutrients in crop yield and nutritional quality enhancement under conditions where the application of macronutrients shows only moderate responses.

The extent of limitation in crop yield seen with using NPK fertilization alone can be further buttressed in other studies. In a World Bank-commissioned survey (Liverpool-Tasie et al. 2015), it was shown for maize that only an abysmal average yield increase of about $8 \%$ is obtained over control yield, upon the addition of more than an average of $200 \mathrm{~kg} \mathrm{ha}^{-1}$ of NPK fertilizers in Nigerian farms during 2010 and 2012. Although these authors recognized that perhaps not just using mineral fertilizers but also using other crop production inputs such as improved seeds and irrigation, as well as improved crop management practices, is important for enhancing crop performance. While this assumption is largely correct, the report, however, did not acknowledge the significant role that other nutrients such as micronutrients could play in enhancing crop productivity in soils with less natural endowments, even with NPK treatment.
This chapter has provided an in-depth evaluation of the functions of micronutrients in crops, from their physiological basis, to the ecological factors they can address and, ultimately, to the agronomic consequences of their use. Table 2 provides a broad overview of these roles.

\section{Revisiting micronutrients' uptake mechanisms for designing nutrient delivery strategies}

\subsection{Conventional uptake of nutrients: ions}

As indicated in a previous section, the conventional species of micronutrients taken up by crops is ions (Table 1). This process can involve competition among the micronutrient ions for entry into the plant, so that an otherwise beneficial process of nutrient accumulation becomes a limiting factor for efficient utilization of specific micronutrients (Cohen et al. 1997; Alam et al. 2001; Kim and Guerinot 2007; Ghasemi-Fasaei and Ronaghi 2008; Rietra et al. 2015). Here, we will briefly highlight how micronutrients' uptake mechanisms can affect their accumulation in the plant. The uptake of $\mathrm{Fe}, \mathrm{Cu}$, and $\mathrm{Mn}$ is preceded by their conversion to more soluble ionic forms $\left(\mathrm{Fe}^{3+}\right.$ to $\mathrm{Fe}^{2+}, \mathrm{Cu}^{2+}$ to $\mathrm{Cu}^{+}$, and $\mathrm{Mn}^{4+}$ to $\left.\mathrm{Mn}^{2+}\right)$ at the cell plasma membrane. Notably, this process, performed by members of a family of ferric reductases (FRO), is not only nonselective for the metal that is converted (Norvell et al. 1993; Cohen et al. 1997; Robinson et al. 1999; Schaaf et al. 2004; Johnson and Barton 2007; Martínez-Ballesta et al. 2010; Dimkpa et al. 2015a, b) but also occurs in both root and shoot cells (Mukherjee et al. 2006; Martínez-Ballesta et al. 2010). With $\mathrm{Ni}$ and $\mathrm{Zn}$, uptake by plant is in the form of the divalent ions, even though $\mathrm{Ni}$, but not $\mathrm{Zn}$, participates in redox reactions. Upon conversion to a plant-usable form, $\mathrm{Fe}, \mathrm{Cu}, \mathrm{Mn}$, but also $\mathrm{Zn}$ and $\mathrm{Ni}$, are transported into the plant. This process, again, could occur through a shared uptake system involving similar divalent metal transporting enzymes (e.g., ironregulated transporter, IRT) that are present in both root and shoot cells (Connolly et al. 2002, 2003; Ishimaru et al. 2005; Kim and Guerinot 2007; Shanmugam et al. 2011; Sinclair and Krämer 2012). In some plants, the exudation from the root of different metal-binding compounds such as phytosiderophores and organic acids results in the uptake of $\mathrm{Fe}, \mathrm{Cu}, \mathrm{Zn}, \mathrm{Ni}$, and $\mathrm{Mn}$, often by similar metal-binding compounds (Schaaf et al. 2004; Keuskamp et al. 2015). Notably, some of these organic compounds are also present in shoot tissues (Rellán-Álvarez et al. 2011; Correia et al. 2014). With Mo, uptake systems have been identified in root but not in shoot and involve active transport through specific Mo transporters (MOT1) (Tomatsu et al. 2007), as well as unspecifically through the sulfate transporter (Stylosanthes hamata sulfate transporter; SHST1) (Mendel and Schwarz 1999; Alhendawi et al. 2005; Fitzpatrick et al. 2008). Thus, 
Table 4 Responses of macronutrient (N, P, K)-treated crops to micronutrient addition

\begin{tabular}{|c|c|c|c|c|c|c|}
\hline Macronutrient & Micronutrient & $\begin{array}{l}\text { Micronutrient } \\
\left(\mathrm{kg} \mathrm{ha}^{-1}, \mathrm{ppm},\right. \\
\text { or } \%)^{\mathrm{a}} \text { added }\end{array}$ & Crop & $\begin{array}{l}\text { Micronutrient in grain/ } \\
\text { leaf tissue (\% increase } \\
\text { over N, P, K, or other } \\
\text { macronutrients) }\end{array}$ & $\begin{array}{l}\% \text { Yield } \\
\text { (increase } \\
\text { over N, P, K) }\end{array}$ & Reference \\
\hline NPK $(150: 100: 60) \mathrm{kg} \mathrm{ha}^{-1}$ & $\mathrm{Fe}$ & 12 & Wheat & - & 9 & Abbas et al. (2009) \\
\hline $\mathrm{N}\left(80 \mathrm{~kg} \mathrm{ha}^{-1}\right)$ & $\mathrm{Fe}$ & 0.4 & Soybean & - & 10 & Caliskan et al. (2008) \\
\hline NPK $\left(150: 25: 50 \mathrm{~kg} \mathrm{ha}^{-1}\right)$ & $\mathrm{Fe}$ & $1 \%$ (foliar) & Sugarcane (stalk) & $59^{\mathrm{b}}$ & 42 & Mishra et al. (2014) \\
\hline NP $\left(150: 80 \mathrm{~kg} \mathrm{ha}^{-1}\right)$ & $\mathrm{Fe}$ & 0.15 & Wheat & 73 & 7 & Habib (2009) \\
\hline NP $\left(150: 80 \mathrm{~kg} \mathrm{ha}^{-1}\right)$ & $\mathrm{Fe}+\mathrm{Zn}$ & $0.15+0.15$ & Wheat & $64(\mathrm{Fe}) ; 66(\mathrm{Zn})$ & 17 & Habib (2009) \\
\hline NP $\left(150: 80 \mathrm{~kg} \mathrm{ha}^{-1}\right)$ & $\mathrm{Zn}$ & 0.15 & Wheat & 317 & 3 & Habib (2009) \\
\hline $\mathrm{N}(1.5 \%$, foliar $)$ & $\mathrm{Zn}$ & 80 (foliar) & Cauliflower & - & 35 & Yadav et al. (2014) \\
\hline NP $\left(250: 125 \mathrm{~kg} \mathrm{ha}^{-1}\right)$ & $\mathrm{Zn}$ & 12 & Maize & 66 & 24 & Tariq et al. (2014) \\
\hline NP $\left(250: 125 \mathrm{~kg} \mathrm{ha}^{-1}\right)$ & $\mathrm{Zn}$ & $1 \%$ (foliar) & Maize & 98 & 39 & Tariq et al. (2014) \\
\hline NPK (100:22:41) & $\mathrm{Zn}$ & $5.0 \mathrm{ppm}$ & Wheat & 125 & 23 & Singh et al. (2014) \\
\hline NPK $(30: 40: 50) \mathrm{kg} \mathrm{ha}^{-1}$ & $\mathrm{Zn}$ & 0.002 & Peanut & 36 & 10 & Prasad et al. (2012) \\
\hline NP $\left(80: 80 \mathrm{~kg} \mathrm{ha}^{-1}\right)$ & $\mathrm{Zn}$ & 4 & Wheat & 116 & - & Ajiboye et al. (2015) \\
\hline NP (80:50) $\mathrm{kg} \mathrm{ha}^{-1}$ & $\mathrm{Zn}$ & 23 & Safflower & 14 & 18 & Aytac et al. (2014) \\
\hline $\begin{array}{l}\mathrm{P} / \mathrm{Ca} / \mathrm{Mg} \\
\quad\left(100: 200: 100 \mathrm{mg} \mathrm{kg}^{-1}\right)\end{array}$ & $\mathrm{Cu}$ & $1.5 \mathrm{ppm}$ & Wheat & 24 & 63 & Kumar et al. (2009) \\
\hline $\mathrm{P}\left(560 \mathrm{~kg} \mathrm{ha}^{-1}\right)$ & $\mathrm{Cu}$ & 33.6 & Wheat & 16 & 7 & Javadi et al. (1991) \\
\hline NPK $\left(30: 30: 38 \mathrm{mg} \mathrm{kg}^{-1}\right)$ & $\mathrm{Cu}$ & $1.0 \mathrm{ppm}$ & Spinach & 156 & 72 & Obrador et al. (2013) \\
\hline $\mathrm{N}\left(90 \mathrm{~kg} \mathrm{ha}^{-1}\right)$ & $\mathrm{Mn}$ & 500 ppm (foliar) & Wheat & - & 11.3 & Seadh et al. (2009) \\
\hline NPK $\left(150: 25: 50 \mathrm{~kg} \mathrm{ha}^{-1}\right)$ & $\mathrm{Mn}$ & $1.0 \%$ (foliar) & Sugarcane (stalk) & $63^{\mathrm{b}}$ & 62 & Mishra et al. (2014) \\
\hline NPK (232:50:430 $\left.\mathrm{mg} \mathrm{l}^{-1}\right)$ & $\mathrm{Mn}$ & $0.3 \mathrm{ppm}$ & Tomato & 202 & - & Kleiber (2014) \\
\hline NP (12.5:40 kg ha $\left.{ }^{-1}\right)$ & $\mathrm{B}$ & $1.0 \mathrm{ppm}$ & Mung bean & 94 & 24 & $\begin{array}{l}\text { Rajeev and Dinesh } \\
\text { (2014) }\end{array}$ \\
\hline NP $\left(12.5: 40 \mathrm{~kg} \mathrm{ha}^{-1}\right)$ & B & $0.1 \%$ foliar & Mung bean & 161 & 36 & $\begin{array}{l}\text { Rajeev and Dinesh } \\
\text { (2014) }\end{array}$ \\
\hline NPK (100:22:41) & B & $1.5 \mathrm{ppm}$ & Wheat & 169 & 26 & Singh et al. (2014) \\
\hline NPK (100:22:41) & $\mathrm{B}+\mathrm{Zn}$ & $1.5+5.0 \mathrm{ppm}$ & Wheat & 175 (B); 147 (Zn) & 26 & Singh et al. (2014) \\
\hline NP $\left(120: 60 \mathrm{~kg} \mathrm{ha}^{-1}\right)$ & $\mathrm{Cl}$ & 31 & Wheat & - & 9 & Sharma et al. (2006) \\
\hline $\mathrm{N}\left(100 \mathrm{~kg} \mathrm{ha}^{-1}\right)$ & Mo & 0.125 & Sunflower & 1139 & 14 & Škarpa et al. (2013) \\
\hline $\mathrm{N}\left(224 \mathrm{~kg} \mathrm{ha}^{-1}\right)$ & Mo & 0.22 & Tobacco & - & 244 & Sims et al. (1975) \\
\hline
\end{tabular}

${ }^{a}$ Rates are in kilograms per hectare where unspecified

${ }^{\mathrm{b}}$ Plant + ratoon crops

while Mo-related processes could trigger concomitant S supply in the plant, a physiological basis for foliar application as a delivery strategy for Mo remains to be resolved. In the case of $\mathrm{B}$, uptake from the root constitutes both passive and highaffinity active transport systems involving two enzymes: nodulin 26-like intrinsic protein, NIP5, a boric acid channel protein, and BOR1, an exporter involved in xylem loading of B (Reid 2014 and references therein). However, proteins are known that are involved in B uptake in the shoot (Reid 2014 and references therein). Moreover, transport of B could also be nonspecific, as a rice $\mathrm{Si}$ transporter has been shown to be able to transport B as well (Mitani et al. 2008). With Cl, uptake is regulated by a family of unspecific channel proteins that also cotransport $\mathrm{Na}$ and $\mathrm{K}$ ions and present in both root and shoot (Broadley et al. 2012). In essence, the uptake of most ionic micronutrients could occur from both root and shoot. This highlights the possibilities for agronomic fortification via foliar application not only for $\mathrm{Zn}$ and $\mathrm{Fe}$ (the most studied and applied in foliar applications) but also for most other micronutrients.

\subsection{Uptake of nanoparticulate nutrients}

Leveraging advanced spectroscopic and microscopic capabilities such as X-ray absorption spectroscopy (XAS), scanning/ transmission electron microscopy-energy dispersive 
spectroscopy (S/TEM-EDS), confocal laser scanning microscopy (CLSM), and other similar instrumentations, novel evidences are increasingly being presented of alternative uptake into plant tissues of $\mathrm{Fe}, \mathrm{Cu}, \mathrm{Mn}, \mathrm{Ni}, \mathrm{Mo}$, and $\mathrm{Zn}$ in the form of oxides or composite particles (Aubert et al. 2012; Dimkpa et al. 2012b, 2013a, b; Wang et al. 2012a, b; Faisal et al. 2013; Ghafariyan et al. 2013; Pradhan et al. 2013; Bandyopadhyay et al. 2015). This is in contrast to the conventional uptake of micronutrients as ions, hitherto the consensus knowledge. Remarkably, both nanosize (100 nm) and submicron to micron-size ( $>100$ to $\leq 1000 \mathrm{~nm}$ ) particles are detected in planta. However, while it is unclear from these studies whether such micron-size particles assumed their aggregate sizes after internalization as nanoparticles (NPs), the uptake of true micron-size $(1000 \mathrm{~nm})$ particles would not be unexpected, given that bacteria cells of similar size are internalized by plants as endophytes. Moreover, crops are known to be able to take up microsize polymers loaded with drugs (e.g., Zhang et al. 2012). So far, it is not known or suggested whether any active enzyme transport activities are involved in this novel uptake system. However, endocytosis has been evinced as a possible strategy for plant uptake of particulate elements, based on (i) the findings that an inhibitor of plant cell endocytosis resulted in reduced uptake of carbon nanotubes and also (ii) the demonstration that the uptake of intact $\mathrm{CuO}$ particles occurs in cells that show the presence of endosomes (Liu et al. 2009; Nair et al. 2010; Wang et al. 2012a, b).

Notably, the presence of nutrient NPs in shoots has been demonstrated from both root (Zhu et al. 2008; Dimkpa et al. 2012b, 2013a, b; Wang et al. 2012a, b; Ghafariyan et al. 2013; Bandyopadhyay et al. 2015) and foliar (Wang et al. 2013a, b) applications in wheat, watermelon (Citrullus lanatus), corn, alfalfa, pumpkin (C. pepo), and soybean, among other crops. Regardless of the application route, the presence of micronutrient particles could be residual enough to allow transportation from point source to distal plant parts (Wang et al. 2012a, b, 2013a, b), or they could dissolve in planta, sometime after uptake, releasing the cognate metal ions for plant metabolism. This latter possibility is suggested by the in planta formation of metal-organic/amino acids or phosphate complexes (Zhu et al. 2008; Dimkpa et al. 2012b, 2013a, b; Lv et al. 2014).

Two phenomena have been observed that occur similarly with micronutrient ions and NPs as they interact with plant roots. Firstly, as with ionic micronutrients, the potential for competition in the plant uptake process of particulate micronutrients has recently been demonstrated using $\mathrm{CuO}$ and $\mathrm{ZnO}$ NPs. In a study involving bean, a reduction of the shoot levels of Fe, Mn, and $\mathrm{Zn}$ was observed in the presence of $\mathrm{CuO}$ NPs, but cotreatment of the CuO NP-exposed plants with $\mathrm{ZnO}$ NPs lowered the shoot level of $\mathrm{Cu}$ from $\mathrm{CuO}$ NPs, likely due to the alleviation by $\mathrm{ZnO}$ NPs of the inhibition of Fe reductase activity induced by $\mathrm{CuO}$ NPs in the plant (Dimkpa et al. 2015b). Secondly, as shown in a study with wheat, the induction of lateral root proliferation occurs with certain micronutrients, whether as ions or NPs (Stewart et al. 2015 and references therein). These findings indicate the role that ions released from NPs might be playing. We argue that being more cognizant of conventional and novel developments in nutrient uptake mechanisms with fertilizer production in mind could offer possibilities for packaging fertilizers or designing nutrient delivery strategies, as will be discussed subsequently.

\section{Influence of packaging on the bioactivity of micronutrients}

Micronutrients are currently presented to plants as salts (e.g., $\mathrm{FeSO}_{4}, \mathrm{MnSO}_{4}, \mathrm{ZnSO}_{4}$ ), chelated compounds (e.g., Fe/ZnEDTA), or bulk ( $\geq 1000 \mathrm{n}$ ) oxide particles (e.g., $\mathrm{ZnO}$ ) (McBeath and McLaughlin 2014; Monreal et al. 2015). The use of salt micronutrients for fertilizers implies that the nutrients are delivered as soluble ions (Table 1), which are both readily plant-bioavailable and rapidly lost from the soil. In contrast, chelated compounds, though present in soluble form, have longer availability time in the soil, while bulk particulate micronutrients have to first become solubilized in the soil solution, often at slow rates, prior to uptake by the plant (McBeath and McLaughlin 2014). The availability to crops of solubilized micronutrients is dictated by soil factors that often constrain their uptake by plants, leading to low uptake efficiency. Therefore, an important challenge is how to package micronutrients in such a way that (i) their usability by the plant is enhanced, (ii) they become less harmful to the soil due to reduced fixation, (iii) they are safer for the environment with minimal losses, and (iv) they are affordable for farmers and beneficial to farm livelihoods. One technology touted as having some of the greatest promise to address these challenges is nanotechnology (see for, e.g., Liu and Lal 2015; Monreal et al. 2015; Servin et al. 2015a). With nanotechnology, micronutrients can be produced in the nanosize range, with the advantage of initial fast release of plant-usable ions at application and then a more sustained slow release over time (Fig. 3, left panel). Notably, the solubility kinetics of nanoparticles straddles between those of salts and bulk/microparticles (Fig. 3, right panel) and, thus, could result in reduced ionic losses, relative to salts, but increased availability during plant growth, relative to bulk particles.

While a number of studies have comparatively evaluated the efficacy of micronutrients packaged as NPs versus current packaging strategies in enhancing crop growth and the attendant mechanistic aspects (see Liu and Lal 2015), few have done so with respect to assessing the effects on crop yield, nutritional quality, or disease resistance. Delfani et al. (2014) reported increases of 4,46 , and $10 \%$ for yield, iron, and chlorophyll contents, respectively, in black eyed pea (Vigna sinensi L.) foliar-fertilized with NP-Fe, compared to $\mathrm{FeSO}_{4}$. 
$Z n$ oxide [left $Y$ axis] or $Z n$ sulfate [right $Y$ axis] dissolution ( $\%$ of $\mathrm{Zn}$ added)

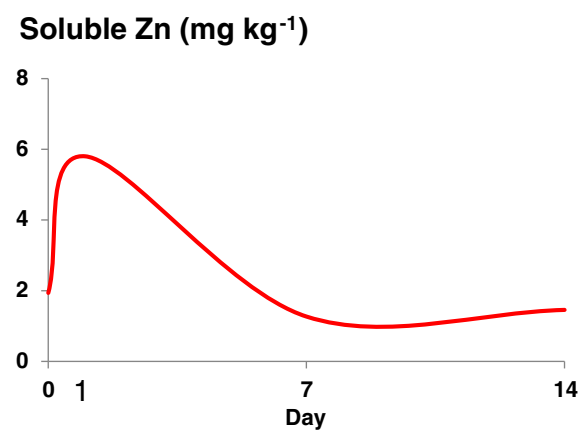

Fig. 3 Patterns of dissolution of ZnO NPs. Left panel, ZnO NPs $\left(500 \mathrm{mg} \mathrm{kg}^{-1}\right)$ at $\mathrm{pH}>7$ in sand. The release of $\mathrm{Zn}$ ions from $\mathrm{ZnO}$ NPs shows an indication of fast early, and subsequent slow, but steady release of nutrients from the NPs. Right panel, comparative release of $\mathrm{Zn}$ from $\mathrm{ZnSO}_{4}, \mathrm{ZnO} \mathrm{NPs}$, and $\mathrm{ZnO}$ bulk. Release rate for $\mathrm{ZnO}$ NPs is intermediate between that of $\mathrm{Zn}$ salt and bulk $\mathrm{ZnO}$, and the release

McBeath and McLaughlin (2014) examined the effects of $\mathrm{ZnO}$ (mostly micron, but also nanosized products), and $\mathrm{ZnSO}_{4}$ on crop morphology, $\mathrm{Zn}$ dissolution, and $\mathrm{Zn}$ accumulation in plant tissues when applied as a soil mixture, or as seed bands. They found similar growth patterns and $\mathrm{Zn}$ accumulation in plant tissues from $\mathrm{ZnO}$ as from $\mathrm{ZnSO}_{4}$, when the products were mixed in the soil, but not when seed-banded, in which case $\mathrm{ZnSO}_{4}$ showed superior performance in terms of solubility rate. Other studies have also reported improved biomass production, seed yield, nutrient content, and/or disease control in different plants treated with $\mathrm{Fe}, \mathrm{Cu}, \mathrm{Mn}$, and $\mathrm{Zn}$ based NPs, relative to their respective salt or bulk counterparts (Prasad et al. 2012; Moghaddasi et al. 2013; Pradhan et al. 2013; Raliya and Tarafdar 2013; Burman et al. 2013; Kim et al. 2014; Servin et al. 2015a, b). Notable among such studies are those highlighted in Fig. 4. These include the enhancement of clusterbean (Cyamopsis tetragonoloba) growth upon foliar application with ZnO NPs (Raliya and Tarafdar 2013), the influence of $\mathrm{ZnO}$ on peanut (Arachis hypogaea) nutrition and yield in the presence of NPK fertilizers (Prasad et al. 2012), which suggests an improvement in NPK use efficiency by the NPs, as well as the reduction of disease progression in eggplant (Solanum melongena), more pronounced with NPs of $\mathrm{CuO}$ and $\mathrm{MnO}$ than with their bulk equivalents (Servin et al. 2015a). Similarly, using macronutrient NPs of P (apatite), Liu and Lal (2014) also demonstrated the greater potential of NPs to enhance crop growth and yield in soybean, compared to bulk $\mathrm{P}$ and calcium phosphate salt (better known as single super phosphate, SSP). These interesting results warrant further comparative studies using micronutrients packaged in different forms, especially in the presence of NPK fertilizers in order to harness the promise of novel

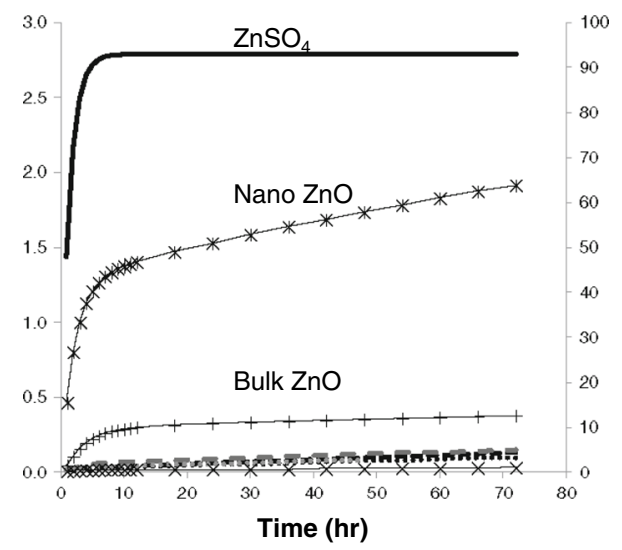

kinetics of the NPs shows a more steady but slow increase over time. For both figures, the crop bioavailability or otherwise of the released nutrients would depend on rhizosphere chemistry, similar to the interaction of soluble salts with soil factors (adapted from Dimkpa et al. 2012a and McBeath and McLaughlin 2014, with permission)

technologies such as nanotechnology, in improving the use efficiency of fertilizers.

\section{Some ways forward}

No single technology may completely resolve the gaps in the crop-human nutrition interface in countries where they exist. However, certain technologies, some novel, others with improvement, can be applied to begin to reduce the gap. We opine that the application of such technology should be rooted on a sound understanding of the biological aspects of nutrientnutrient interactions so that their formulation in fertilizer products can be optimized. In this regard, the previous discussions of micronutrient uptake mechanisms and interactions are vital in understanding how and why, ironically, micronutrients may limit the yield or affect the overall nutritional quality of crops (see Fageria 2001). From a practical application standpoint, being more cognizant of the agronomic implications of the competitive nature of micronutrient uptake could permit the formulation of micronutrient fertilizers that precludes competition among nutrients that use similar uptake pathways, either by balancing the nutrient ratios, applying such nutrients at different times, or administering them via alternative routes such as through foliar versus soil. Such choices should be guided by knowledge of which plant portion, shoot or root, specific micronutrients are most required, as well as the potential uptake pathway for such micronutrients (Fig. 5).

From a fertilizer production standpoint, promising technologies that would require dissemination to countries with micronutrient use deficit in order to achieve efficiency in micronutrient agronomic fortification should be promoted. For 


\section{Biomass enhancement}
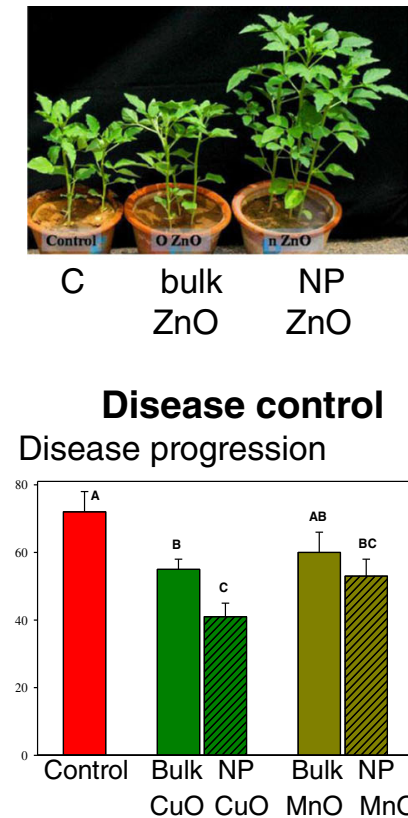

Fig. 4 Different effects of micronutrients (Micronutrients) on crops, illustrating their use as a one-stop shop for enhancing crop productivity. This illustration is based on actual results from discrete studies for crop performance indicators (biomass enhancement, suppression of disease progression, enhanced nutrient fortification, and enhanced yield) evoked by micronutrients in the absence or presence of NPK fertilizers. Because micronutrients packaged and delivered to crops as nanoparticles (NPs) often demonstrate superiority in performance indicators over salts

instance, micronutrient-amended macronutrients can be produced by fertilizer production plants without significantly disrupting the production process. In this case, the micronutrients could be added at the end of the macronutrient production line by coating the finished macronutrient granules with salts or oxide powders of micronutrients, using materials as common as vegetable oil, or other industrial coating products, with environmental biocompatibility in mind. The coated oxide micronutrients should be stable on the macronutrient surface, since they are unhydrated. Although oxides are generally less soluble than hydrated salts, their solubility may not be stifled, depending on the chemistry of the macronutrient (see for, e.g., Milani et al. 2012, 2015). For example, ZnO would be solubilized in the acid environment produced from the dissolution and nitrification of ammonium phosphate or ammonium sulfate macronutrients. In any case, the undesirable impact of their lower solubility would be lessened by the fact that oxide micronutrients are able to penetrate into the plant at both nano and microscales (see previous section). The agronomic and nutritional relevance of micronutrient coating onto macronutrients was evidenced in the study of Shivay et al. (2008) with $\mathrm{Zn}$ and urea in rice, showing up to 16-20, 24-29, and 42-57\% increases in biomass, grain yield, and grain $\mathrm{Zn}$ nutritional quality, respectively, at $5.2 \mathrm{~kg} \mathrm{Zn}$

\section{Nutrient fortification}
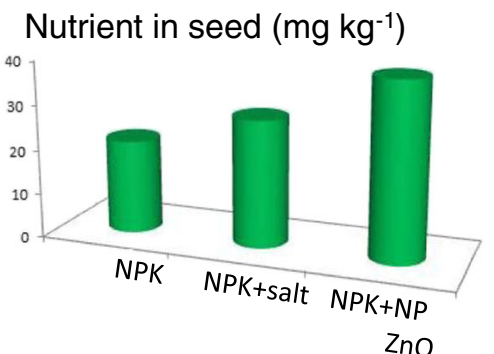

Yield enhancement

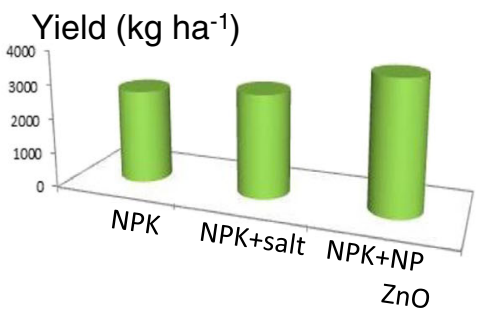

or bulk micronutrients, these outcomes could be taken as a collective research focus involving the development and use of novel micronutrient-packaging strategies, namely nanoparticles, for enhanced crop performance over bulk minerals or nutrient salts administered through different plant organs. Image modified from Prasad et al. (2012), Raliya and Tarafdar (2013), and Servin et al. (2015a), with permission

$\mathrm{ha}^{-1}$, dependent on whether oxide or $\mathrm{Zn}$ salt was used for coating. With other macronutrient sources such as urea, different technologies for micronutrient amendment may have to be devised, since urea could be alkaline, potentially impeding micronutrient dissolution (Milani et al. 2012, 2015). In this case, macronutrient-micronutrient core technology can be pursued, such as swapping the core of urea granules with one or more micronutrient cores. Upon dissolution of the urea in the crop rhizosphere, the micronutrient in the core would be exposed and liberated for plant use. Having the micronutrient inside the urea has the advantage of preventing the physical segregation of the much smaller micronutrients from the larger urea granules during product storage, transportation, and/or usage. The urea- $\mathrm{Zn}$ core technology is currently being promoted by the IFDC and VFRC, where preliminary agronomic assessments indicate significantly higher $\mathrm{Zn}$ content in spinach biomass, relative to no $\mathrm{Zn}$ treatment.

Coming back to nanotechnology, one of the most notable characteristics of nanoparticulate micronutrients is the greatly enhanced availability to, and translocation within, the plant (Wang et al. 2012a, b). Thus, this newly discovered possibility of micronutrient uptake as particles from both shoot and root could direct completely novel R\&D efforts in fertilizer delivery strategies that allow uptake of nanopackaged 


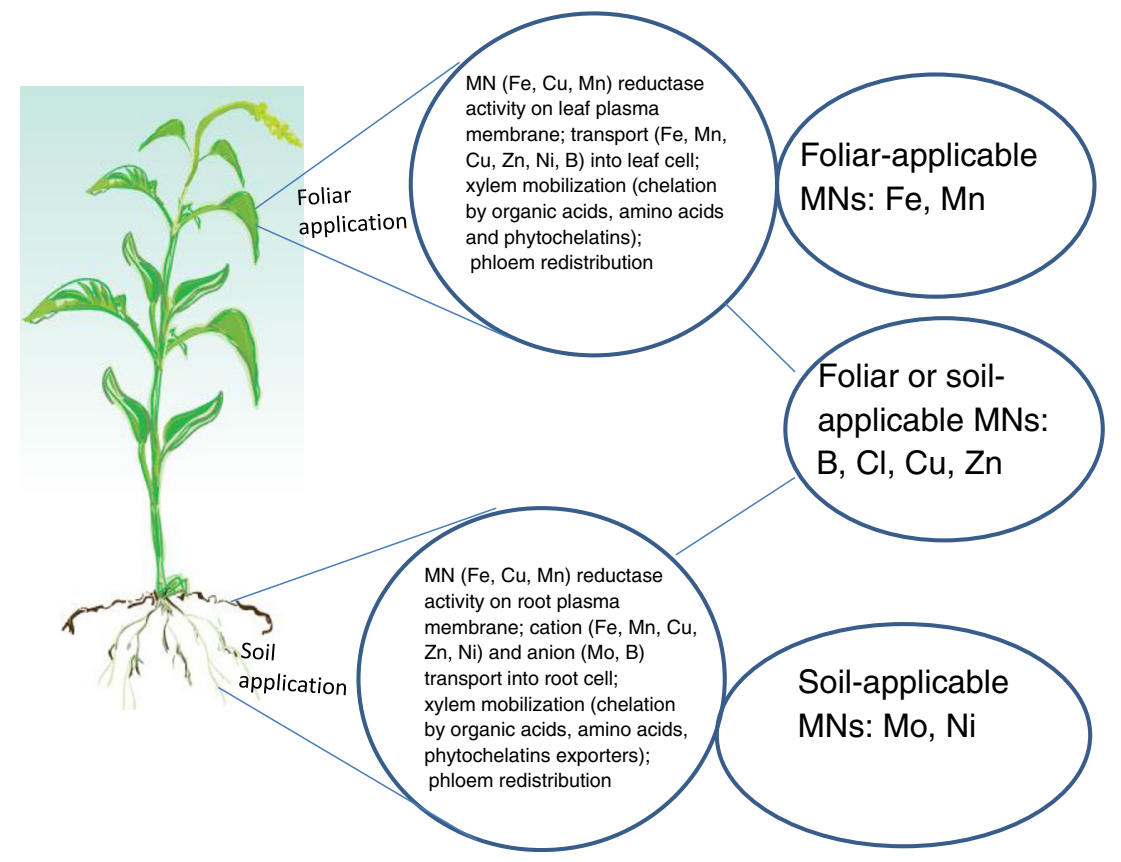

Fig. 5 Physiological evidence of overlaps in the root and shoot uptake pathways for micronutrients (Micronutrients). Metallic reductases, divalent metal transporters, and xylem transport facilitators are present in both shoot and root tissues to direct cation accumulation into the plant, irrespective of application point. The similarity between the root and shoot pathways for several of the micronutrients suggests that delivering the nutrients via the foliar pathway should be a feasible strategy for many crops. However, specific micronutrients appear to be more physiologically relevant either in the shoot or root. On the basis of

micronutrients, so that they accumulate, are redistributed, and solubilized inside plant tissues, as shown for $\mathrm{Cu}, \mathrm{Zn}$, and also Mg (Dimkpa et al. 2012b, 2013a, b; Wang et al. 2012a, b, 2013a, b; Lv et al. 2014). Nanofertilizers are already used in crop production in China, but reported only for urea (Huang et al. 2015), and should therefore be extended to micronutrients. Nanopackaging can be leveraged to reduce nutrient losses to the environment (Huang et al. 2015; Liu and Lal 2015), which is characteristic of nutrients administered as soluble salts. Moreover, by providing alternative uptake pathways through the internalization of intact particles, ionic nutrient competition could be circumvented during uptake from shared pathways. We have hereby coined a term, "micnobits," in depiction of tiny (micro and nanosize) particulate micronutrient fertilizer products that can be taken up as intact particles by plants, for release of the active ingredients in planta.

Accordingly, micronutrient "micnobits" packaging or delivery can proceed under two pathways. On the one hand, micronutrients of $\mathrm{Zn}, \mathrm{Fe}, \mathrm{Cu}, \mathrm{Mn}, \mathrm{Mg}, \mathrm{Ni}, \mathrm{B}$, and Mo can be delivered as particles that can either be taken up directly by the plant or be solubilized in the rhizosphere prior to uptake of the cognate ionic species. Bulk rock P particles can be prepared as nanoformulations by milling, or nano $\mathrm{P}$ (hydroxyapatite) can be synthesized by a precipitation such organ-specific biological needs, foliar application could be suggested for $\mathrm{Fe}, \mathrm{Cu}, \mathrm{Mn}$, and $\mathrm{Zn}$, all of which influence leaf-related biochemical process such as chlorophyll biosynthesis and photosynthesis. In contrast, $\mathrm{Mo}$ and $\mathrm{Ni}$, both of which activate enzymes involved in $\mathrm{N}$ metabolism in the root, could be provided via soil application. Boron, $\mathrm{Cl}$, and $\mathrm{Cu}$ could be provided through both foliar and soil, as they are functional in maintaining the integrity of cell walls of any organ type, while $\mathrm{Zn}$, due to its involvement in hormonal activities, could be provided as both foliar and soil-applied

chemical reaction involving phosphoric acid and calcium hydroxide P (Liu and Lal 2014, 2015). On the other hand, "micnobits" micronutrients can be encapsulated in nanopolymers or macronutrients (e.g., urea-nano $\mathrm{Zn}$ core technology) that serve as delivery systems into the plant, with the expectation that the cognate nutrient would be released in the rhizosphere or in planta. Nanoencapsulation of micronutrients is a research area where knowledge gaps still exist, for although the ability of crops to take up nano and micron-size polymers loaded with drugs have been demonstrated (e.g., Zhang et al. 2012), the uptake of such polymers when loaded with nutrients, as well as the potential for release of the encapsulated nutrients inside the plant cell, is yet to be understood. In this regard, lessons could be learned from two facts (i) that bare metallic nutrient NPs are taken up and (ii) that polymer technology is at the core of controlled-release fertilizers (Timilsena et al. 2015). Hence, nanopolymers could be engineered to timely dissolve in the rhizosphere, releasing the encapsulated nutrients in sync with the plant's need (Monreal et al. 2015; Timilsena et al. 2015). Recently, Monreal et al. (2015) proposed the integration into nanopolymer technology for micronutrient fertilizers of biosensors that are based on, and therefore respond to, specific nutrient-solubilizing root exudate signals. Notably, it has been shown that specific chemicals contained in root exudates 
known to function in solubilizing nutrients from otherwise insoluble sources from the soil also regulate the dissolution of micronutrient NPs (Martineau et al. 2014). In addition to the individual mineral nutrients, composite NPs of different but compatible (i.e., nonantagonistic) nutrients also can be delivered via soil or foliar application into plant tissues, where they slowly dissolve to release the cognate ions for plant assimilation, goaded by specific environmental signals. As indicated previously, NP micronutrients have shown a dissolution rate (slower than salts but faster than bulk particles) that can potentially benefit the environment in either of two ways, dependent on the agroecology. Slow release of NP-based fertilizers, which implies that both leaching and fixation of nutrients inherent with use of salts could be reduced, would permit a better timing of nutrient availability and plant nutrient needs. This aspect of nano application could be useful in agroecologies experiencing the negative consequences of fertilizer overuse. In the case of nutrient-deficient tropical soils, because NPs inherently release soluble ions faster than bulk particles, enhanced and sustained release of nutrients from NPs will be important in supplying nutrients in a timely and sustainable manner, in contrast to bulk NM particles, while avoiding the rapid losses associated with the use of salts.

Regarding the profitability of the adoption of micronutrients in fertilizer regimes, we shall make the case using information reported in Servin et al. (2015b). In the study, eggplants were foliar-fertilized with an equal dose of bulk $\mathrm{CuO}(\$ 18.5 /$ bottle) and nano $\mathrm{CuO}(\$ 44 /$ bottle), and with a control treatment of no $\mathrm{Cu}$ amendment. During a two-season (2013 and 2014) experimental period, yield increases over the control of 17 and $31 \%$ and of 45 and $58 \%$, respectively, were obtained from the bulk and nano $\mathrm{CuO}$ treatments. At the density of 3500 plants per acre used in the study, 17,500 fruits per acre would be produced, assuming a single plant produces five fruits. The authors made other assumptions regarding the cost $(\$ 1 / \mathrm{lb}$.) and weight (1 lb.) of a fruit. With these assumptions, the control plants would generate $\$ 17,500$ in monetary terms. For the treatments, an averaged \% increase in yield from using the bulk and nano $\mathrm{CuO}$ for the two seasons would translate to $\$ 21,700$ and $\$ 26,337$, respectively. These values indicate that a \$26 (\$44-\$18.5) extra investment in nano $\mathrm{Cu}$ fertilizer could generate a profit of $\$ 4637$ over conventional $\mathrm{Cu}$ fertilizer. Nevertheless, it is necessary to emphasize that the use of micronutrient fertilizers to fortify crops in certain socioeconomic conditions may be unfeasible, due to lack of resources for farmers to do so. In such cases, subsidies could be provided by governments. The feasibilities and methodologies for dispensing such subsidies are beyond the scope of this review.

Despite these potential benefits, the application of nanotechnology in plant fertilization could come with unintended environmental consequences for crops and crop-associated beneficial microorganisms (see for example, Dimkpa 2014), especially when misused. The nature and scope of such unwanted effects would depend on the nanomaterial in question, the fate of the nanomaterial (stabilized, aggregated, or solubilized) in the environment, the biological species exposed, and especially, the exposure dose. Regarding dose effects, it is worth mentioning that most of the plant-nanoparticle interaction studies involving micronutrients, for which negative effects are reported, have been conducted using high doses (in some cases up to $1000 \mathrm{mg} \mathrm{kg}^{-1}$; Aslani et al. 2014; Dimkpa et al. 2012a; Gardea-Torresdey et al. 2014). In reality, orders of magnitude lower doses of micronutrients are needed by plants for agronomic efficiency. The disconnect between the choices of NP doses for toxicological and agronomic purposes may explain the widely held view that nanoscale micronutrients are by default inherently highly phytotoxic. In contrast to such views, the use of micronutrient NPs in soil at low doses has consistently been demonstrated to be beneficial to plants (Gardea-Torresdey et al. 2014 and also other references in this article). Even for silver (Ag) NPs (Ag is among the most toxic trace metals, and a nonnutrient), exposure at low doses does, in fact, stimulate plant productivity (Gardea-Torresdey et al. 2014; Wang et al. 2013a, b). Moreover, even at high doses (e.g., $500 \mathrm{mg} \mathrm{kg}^{-1}$ ), soil chemistry (e.g., $\mathrm{pH}$ ) could modulate the outcome of NP interaction with plants (Watson et al. 2015). For these reasons, the promised benefits from nanotechnology could be hamstrung by inaccurate prediction or perception of the risks associated with the use of nanomaterials in environmental systems (see also Holden et al. 2014). Thus, we argue that while each NP has to be examined on its own merit for its effects in different plantsoil systems, in general, the exposure dose and environmental chemistry may be more important in making the "poison" than the "nano" nature of the NP. Indeed, the risks from NPs appear to be either less potent, or no more potent, than risks provoked by salt micronutrients at similar application doses (Kim et al. 2014; Kouhi et al. 2014; Bandyopadhyay et al. 2015). In any case, the judicious use of micronutrients, irrespective of the form in which they are packaged, is important for maximizing benefits while minimizing risks.

There is no overstating the need that the production of micronutrient fertilizers should advance from bulk engineering and chemistry to bio-nano-chemistry. To this end, knowledge aimed at identifying plant-based chemicals (e.g., root exudates) for signaling nutrient deficiency and packaging of nutrients (Monreal et al. 2015; Keuskamp et al. 2015) should be pursued rigorously, to arrive at strategies to precisely deliver micronutrients and other nutrients into the plant, thereby reducing the contact of active ingredients in fertilizers with the wider environment. Such knowledge can be derived from that in the food and pharmaceutical industry, where bioactive ingredients are packaged fit to meet human metabolic processes, such as passing through the acid stomach. 
Revisiting the uncertainty surrounding global micronutrient availability (Table 1), there is a need for micronutrients to be more dedicated to agricultural uses. To this end, it is suggested that alternative chemicals or materials be used more for nonagricultural industrial applications in which micronutrients are currently used. Here, we buttress further using as example $\mathrm{Zn}$ - the micronutrient whose forecasted depletion seems direct. In this case, instead of $\mathrm{Zn}$, aluminum (Al), plastic, and steel can replace galvanized plates; $\mathrm{Al}$ and plastics can replace $\mathrm{Zn}$ in spray-casting; $\mathrm{Al}$ alloys, cadmium $(\mathrm{Cd})$, and paint can provide alternative uses for $\mathrm{Zn}$ in protecting materials against corrosion; and $\mathrm{Al}$ alloys could be used in brass messing instead of $\mathrm{Zn}$. In fact, several other elements can replace $\mathrm{Zn}$ in chemicals, electronics, pigments, and tires, where they are typical additives (Chardon and Oenema 2013). Similarly, such alternative nonmicronutrient elements or compounds can be found for other micronutrients whose availability is also becoming limited. Along the same line, the utilization of alternatives for $\mathrm{Zn}$ in nonagricultural products can be accompanied by recovery of $\mathrm{Zn}$ from such products and its reuse for crop production. A good example is the case of $\mathrm{Zn}$ recycling from vehicle tires, which has shown strong potential as $\mathrm{Zn}$ fertilizers. Vehicle tire rubber contains about $1 \% \mathrm{Zn}$ (Councell et al. 2004); when ground, this could be concentrated to between 15 and $20 \mathrm{~g} \mathrm{Zn} \mathrm{kg}^{-1}$ (Taheri et al. 2011). The application of Zn-containing ground or burned (ash) vehicle tire as fertilizers has been demonstrated to increase both the yield and $\mathrm{Zn}$ content of food crops (Khoshgoftarmanesh et al. 2012, 2013; Moghaddasi et al. 2013; Taheri et al. 2011).

It is very likely that the USGS primary data used in Table 1 captured only global micronutrient resources that are significant. Thus, there likely are several small pockets of micronutrient deposits, especially in Sub-Saharan African countries, that could and should be harnessed for local blending of micronutrient fertilizers. In agricultural terms, extending the temporal availability of micronutrients by using alternative elements for nonagricultural applications and by recycling or identifying and using local micronutrient resources for fertilizers would be vital for ensuring that short-term crop-human nutrition enhancement programs such as micronutrient agronomic fortification not only render immediate impactful outcomes but that they are also sustainable.

Given that the possibility of exhausting the global micronutrients reserves may only be delayed but not completely halted, agronomic fortification will ultimately need to be integrated with genetic (bio)fortification efforts. Despite the scenario suggested in Table 1, there are micronutrients in many soils. They are only poorly available to the plant, dependent on soil chemistry, hence the need to supplement them in soil. As indicated previously, many crops elaborate nutrient-scavenging mechanisms, including the secretion of organic acids and metal chelators that help dissolve and capture fixed minerals, particularly under alkaline conditions into which group about $30 \%$ of the world's arable soils are classified. Biofortification research should focus on selecting, breeding, or engineering crops with enhanced ability to secrete organic acids and other exudates and/or to elaborate heightened reductase and phosphatase enzyme activities to tap soil micronutrient resources of $\mathrm{Fe}, \mathrm{Zn}, \mathrm{Mn}, \mathrm{Cu}$, and $\mathrm{Ni}$. Focus should also be on generating plant varieties with desirable traits (e.g., longer roots, enhanced lateral roots, and enhanced transpiration rate, for the uptake of most micronutrients) (White et al. 2013). This will ensure that crop cultivars with the greatest ability to scavenge for micronutrients in soils of any nutrient status, rich or poor, and translocate them efficiently to edible plant parts predominate the farming systems. With that, and depending on the agricultural region in question, even less new micronutrient addition to soils might be necessary, thus prolonging the availability of the continuously dwindling agronomic micronutrient resources. Also, packaging of micronutrients as "micnobits" fertilizers would result in less overall micronutrient use, as uptake efficiency would improve relative to salts, especially if the active ions are released in planta. Furthermore, in the event of release of ions in the rhizosphere, the intermediate solubilization pattern anticipated from a fertilizer comprising of a mixture of nano and microsize nutrient particles will permit both immediate and residual availability of the nutrients in the soil.

\section{Concluding remarks}

We reckon that it would not be possible, or even necessary, to have in one single fertilizer product a balanced composition with all 14 nutrients, due to the large spatial variation in soil characteristics, the temporal needs for different nutrients by crops, and the negative nutrient interactions that occur. As such, nutrient omission and/or addition trials that elucidate the relative influence of each nutrient under specific crop and agroecological situations should guide innovations in designing and formulating fertilizer products. That way, only the right nutrient combinations are used for the right crop and at the right place and time, reflecting the 4Rs nutrient stewardship philosophy. The bottom line is that, for most farmers, the use of fertilizers should go beyond the big three (NPK), to include micronutrients, but on a case-by-case basis. Such use should be sensitive to agroecological and soil peculiarities and have human dietary requirements as targets.

In spite of the vast evidence that NPK-fed crops would thrive better and produce greater yield in the presence of micronutrients, most fertilizer formulations lack micronutrient amendments. The foregoing discussions clearly demonstrate that the outcome of good use of micronutrients is improved yield, quality, and health of the crop. Viewed holistically as we 
have attempted to do in this review, these roles present micronutrients as all-in-one input factor for sustainable and profitable crop production. As illustrated in Fig. 4, the possibility of using micronutrients as a one-stop shop for increasing crop biomass production, enhancing yield, suppressing crop diseases, and fortifying crops with nutrients is real. The numerous lines of evidence presented in this study suggest that this potential may be valid regardless of the NPK status of the system, and is significantly influenced by the nature of the micronutrients, with NPs appearing to demonstrate greater effects than salts or bulk nutrients. To the best of our knowledge, no studies have experimentally examined these multiple goals simultaneously using micronutrients. We surmise that valuable fundamental and applied knowledge would be gained from research that systematically investigate the use of differently packaged (salts, chelates, bulk particles, nanoparticles, and "micnobits") micronutrients to address this research gap, taking into cognizance the likelihood that differently packaged micronutrients could have different beneficial threshold levels, so that benefits can variably transform into toxic outcomes.

Acknowledgments Funding for this work is provided, in part, by the United States Agency for International Development (USAID). We would like to thank Susan Yiapan for assistance with internal editorial review of this manuscript and Dr. John Wendt for providing the photograph in Fig. 1.

\section{References}

Abbas G, Khan MQ, Khan MJ, Hussain F, Hussain I (2009) Effect of iron on the growth and yield contributing parameters of wheat (Triticum aestivum L.). The J Animal Plant Sci 19:135-139

Ahmed N, Abid M, Ahmad F, Ullah MA, Javaid Q, Ali MA (2011) Impact of boron fertilization on dry matter production and mineral constitution of irrigated cotton. Pakistan J Bot 43:2903-2910

Ajiboye B, Cakmak I, Paterson D, de Jonge MD, Howard DL, Stacey SP, Torun AA, Aydin N, McLaughlin MJ (2015) X-ray fluorescence microscopy of zinc localization in wheat grains biofortified through foliar zinc applications at different growth stages under field conditions. Plant Soil 392:357-370. doi:10.1007/s11104-015-2467-8

Akeredolu I, Oguntona BE, Okafor C, Osisanya OJ (2011) Iron, zinc, and copper malnutrition among primary school children in Lagos, Nigeria. Food Nutri Sci 2:1063-1070. doi:10.4236/fns.2011. 210142

Alam S, Kamei S, Kawai S (2001) Effect of iron deficiency on the chemical composition of the xylem sap of barley. Soil Sci Plant Nutr 47: 643-649. doi:10.1080/00380768.2001.10408428

Al-Amery MM, Hamza JH, Fuller MP (2011) Effect of boron foliar application on reproductive growth of sunflower (Helianthus annuus L.). Int J Agron 2011:230712. doi:10.1155/2011/230712

Alhendawi RA, Kirkby EA, Pilbeam DJ (2005) Evidence that sulfur deficiency enhances molybdenum transport in xylem sap of tomato plants. J Plant Nutr 28:1347-1353. doi:10.1081/PLN-200067449

Alidoust D, Isoda A (2013) Effect of gamma $\mathrm{Fe}_{2} \mathrm{O}_{3}$ nanoparticles on photosynthetic characteristic of soybean (Glycine max (L.) Merr.): foliar spray versus soil amendment. Acta Physiol Planta 35:33653375. doi:10.1007/s11738-013-1369-8
Allen HE (2002) Bioavailability of metals in terrestrial ecosystems: importance of partitioning for bioavailability to invertebrates, microbes, and plants. SETAC Foundation, Florida, USA

Alloway BJ, Jackson AP (1991) The behavior of heavy-metals in sewage sludge-amended soils. Sci Total Environ 100:151-176. doi:10.1016/ 0048-9697(91)90377-Q

Ashraf MY, Iqbal N, Ashraf M, Akhter J (2014) Modulation of physiological and biochemical metabolites in salt stressed rice by foliar application of zinc. J Plant Nutr 37:447-457. doi:10.1080/ 01904167.2013.864309

Aslani F, Bagheri S, Nurhidayatullaili MJ, Juraimi AS, Hashemi FSG, Baghdadi A (2014) Effects of engineered nanomaterials on plants growth: an overview. Sci World J: 641759. doi:10.1155/2014/ 641759

Aubert T, Burel A, Esnault MA, Cordier S, Grasset F, Cabello-Hurtado F (2012) Root uptake and phytotoxicity of nanosized molybdenum octahedral clusters. J Hazard Mater 219-220:111-118. doi:10. 1016/j.jhazmat.2012.03.058

Aytac Z, Gulmezoglu N, Sirel Z, Tolay I, Torun AA (2014) The effect of zinc on yield, yield components and micronutrient concentrations in the seeds of safflower genotypes (Carthamus tinctorius L.). Not Bot Horti Agrobo 42:202-208

Bagci SA, Ekiz H, Yilmaz A, Cakmak I (2007) Effects of zinc deficiency and drought on grain yield of field-grown wheat cultivars in Central Anatolia. J Agron Crop Sci 193:198-206. doi:10.1111/j.1439-037X. 2007.00256.x

Bai C, Reilly CC, Wood BW (2006) Nickel deficiency disrupts metabolism of ureides, amino acids, and organic acids of young pecan foliage. Plant Physiol 140:433-443. doi:10.1104/pp.104.900185

Baligar VC, Fageria NK, He ZL (2001) Nutrient use efficiency in plants. Commun Soil Sci Plant Anal 32:921-950. doi:10.1081/CSS100104098

Bandyopadhyay S, Plascencia-Villa G, Mukherjee A, Rico CM, JoséYacamán M, Peralta-Videa JR, Gardea-Torresdey JL (2015) Comparative phytotoxicity of $\mathrm{ZnO} \mathrm{NPs}$, bulk $\mathrm{ZnO}$, and ionic zinc onto the alfalfa plants symbiotically associated with Sinorhizobium meliloti in soil. Sci Total Environ 515:60-69. doi:10.1016/j. scitotenv.2015.02.014

Barron AR, Wurzburger N, Bellenger JP, Wright SJ, Kraepiel AML, Hedin LO (2009) Molybdenum limitation of asymbiotic nitrogen fixation in tropical forest soils. Nat Geosci 2:42-45. doi:10.1038/ ngeo366

Bereuter D, Glickman D (2015) Healthy food for a healthy world: leveraging agriculture and food to improve global nutrition. The Chicago Council on Global Affairs http://www.thechicagocouncil. org/sites/default/files/GlobalAg-HealthyFood_FINAL.pdf. Accessed 9 Nov 2015

Bindraban PS, Dimkpa CO, Nagarajan L, Roy AH, Rabbinge R (2015) Revisiting fertilisers and fertilisation strategies for improved nutrient uptake by plants. Biol Fertil Soils 51:897-911. doi:10.1007/s00374015-1039-7

Boyd RS, Shaw JJ, Martens SN (1994) Nickel hyperaccumulation defends Streptanthus polygaloides (Brassicaceae) against pathogens. Ame J Bot 81:294-300. doi:10.1007/s00374-015-1039-7

Broadley MR, White PJ, Bryson RJ, Meacham MC, Bowen HC, Johnson SE, Hawkesford MJ, McGrath SP, Zhao FJ, Breward N, Harriman M, Tucker M (2006) Biofortification of UK food crops with selenium. Proc Nutr Soc 65:169-181. doi:10.1079/PNS2006490

Broadley M, Brown P, Cakmak I, Rengel Z, Zhao F (2012) Functions of nutrient: micronutrients. In: Marschner P (ed) Marschner's mineral nutrition of higher plants, 3rd edn. Elsevier, Oxford, pp 243-248

Brodrick SJ, Amijee F, KipeNolt JA, Giller KE (1995) Seed analysis as a means of identifying micronutrient deficiencies of Phaseolus vulgaris $\mathrm{L}$ in the tropics. Trop Agric 72:277-284

Burman U, Saini M, Kumar P (2013) Effect of zinc oxide nanoparticles on growth and antioxidant system of chickpea seedlings. Toxicol 
Environ Chem 95(4):605-612. doi:10.1080/02772248.2013. 803796

Cakmak I (2000) Tansley review no. 111-possible roles of zinc in protecting plant cells from damage by reactive oxygen species. New Phytol 146:185-205. doi:10.1046/j.1469-8137.2000.00630.x

Cakmak I (2008) Enrichment of cereal grains with zinc: agronomic or genetic biofortification? Plant Soil 302:1-17. doi:10.1007/s11104007-9466-3

Cakmak I (2009) Enrichment of fertilizers with zinc: an excellent investment for humanity and crop production in India. J Trace Elements Med Biol 29:281-289. doi:10.1016/j.jtemb.2009.05.002

Cakmak I, Pfeiffer WH, McClafferty B (2010) Biofortification of durum wheat with zinc and iron. Cereal Chem 87:10-20. doi:10.1094/ CCHEM-87-1-0010

Caliskan S, Ozkaya I, Caliskan ME, Arslan M (2008) The effects of nitrogen and iron fertilization on growth, yield and fertilizer use efficiency of soybean in a Mediterranean-type soil. Field Crops Res 108:126-132. doi:10.1016/j.fcr.2008.04.005

Chardon WJ, Oenema O (2013) Exploration of possible scarcity of micro nutrients in the food system. Rep 2413. Alterra Wageningen http:// edepot.wur.nl/257460. Accessed 9 Nov 2015.

Cohen CK, Norvell WA, Kochian LV (1997) Induction of the root cell plasma membrane ferric reductase. An exclusive role for $\mathrm{Fe}$ and $\mathrm{Cu}$. Plant Physiol 114:1061-1069. doi:10.1104/pp.114.3.1061

Connolly EL, Fett JP, Guerinot ML (2002) Expression of the IRT1 metal transporter is controlled by metals at the levels of transcript and protein accumulation. Plant Cell 14:1347-1357. doi:10.1105/tpc. 001263

Connolly EL, Campbell NH, Grotz N, Prichard CL, Guerinot ML (2003) Overexpression of the FRO2 ferric chelate reductase confers tolerance to growth on low iron and uncovers posttranscriptional control. Plant Physiol 133:1102-1110. doi:10.1104/pp.103.025122

Correia PJ, Gama F, Saavedra T, Miguel MG, Da Silva JP, Abadia A, de Varennes A, Pestana M (2014) Changes in the concentration of organic acids in roots and leaves of carob-tree under Fe deficiency. Funct Plant Biol 41:496-504. doi:10.1071/FP13204

Councell TB, Duckenfield KU, Landa ER, Callender E (2004) Tire-wear particles as a source of zinc to the environment. Environ Sci Technol 38:4206-4214. doi:10.1021/es034631f

da Silveira VC, Fadanelli C, Sperotto RA, Stein RJ, Basso LA, Santos DS, da Silva Vaz Junior I, Dias JF, Fett JP (2009) Role of ferritin in the rice tolerance to iron overload. Sci Agric (Piracicaba, Braz) 66: 549-555. doi:10.1590/S0103-90162009000400019

Datnoff LE, Elmer WH, Huber DM (2007) Mineral nutrition and plant disease. The American Phytopathological Society, St. Paul

Davis DR, Epp MD, Riordan HD (2004) Changes in USDA food composition data for 43 garden crops. J Ame Coll Nutr 23:669-682

Udo de Hais HA, Voortman, RL, Bastein T, Bussink DW, Rougoor CW, van de Weijen WJ (2012) Scarcity of micronutrients in soil, feed, food and mineral reserves - urgency and policy options. Platform Agriculture, Innovation and Society (PAIS), The Netherlands. http:// www.iatp.org/files/scarcity of micronutrients.pdf. Accessed 9 Nov 2015

Delfani M, Firouzabadi MB, Farrokhi N, Makarian H (2014) Some physiological responses of black-eyed pea to iron and magnesium nanofertilizers. Commun Soil Sci Plant Anal 45:530-540. doi:10. 1080/00103624.2013.863911

Dimkpa CO (2014) Can nanotechnology deliver the promised benefits without negatively impacting soil microbial life? J Basic Microbiol 54:889-904. doi:10.1002/jobm.201400298

Dimkpa CO, Merten D, Svatoš A, Büchel G, Kothe E (2009) Metalinduced oxidative stress impacting plant growth in contaminated soil is alleviated by microbial siderophores. Soil Biol Biochem 41: 154-162. doi:10.1016/j.soilbio.2008.10.010

Dimkpa CO, McLean JE, Britt DW, Anderson AJ (2012a) Bioactivity and biomodification of $\mathrm{Ag}, \mathrm{ZnO}$ and $\mathrm{CuO}$ nanoparticles with relevance to plant performance in agriculture. Indust Biotech 8: 344-357. doi:10.1089/ind.2012.0028

Dimkpa CO, McLean JE, Latta DE, Manangón E, Britt DW, Johnson WP, Boyanov MI, Anderson AJ (2012b) $\mathrm{CuO}$ and $\mathrm{ZnO}$ nanoparticles: phytotoxicity, metal speciation and induction of oxidative stress in sand-grown wheat. J Nanopart Res 14:1125. doi:10.1007/s11051012-1125-9

Dimkpa CO, Latta DE, McLean JE, Britt DW, Boyanov MI, Anderson AJ (2013a) Fate of $\mathrm{CuO}$ and $\mathrm{ZnO}$ nano- and microparticles in the plant environment. Environ Sci Technol 47:4734-4742. doi:10.1021/ es304736y

Dimkpa CO, McLean JE, Britt DW, Anderson AJ (2013b) Antifungal activity of $\mathrm{ZnO}$ nanoparticles and their interactive effect with a biocontrol bacterium on growth antagonism of the plant pathogen, Fusarium graminearum. BioMetals 26:913-924. doi:10.1007/ s10534-013-9667-

Dimkpa CO, Hansen T, Stewart J, McLean JE, Britt DW, Anderson AJ (2015a) $\mathrm{ZnO}$ nanoparticles and root colonization by a beneficial pseudomonad influence metal responses in bean (Phaseolus vulgaris). Nanotoxicol 9:271-278. doi:10.3109/17435390.2014. 900583

Dimkpa CO, McLean JE, Britt DW, Anderson AJ (2015b) Nano-CuO and interaction with nano- $\mathrm{ZnO}$ or soil bacterium provide evidence for the interference of nanoparticles in metal nutrition of plants. Ecotoxicol 24:119-129. doi:10.1007/s10646-014-1364-x

Duffner A, Hoffland E, Stomph TJ, Melse-Boonstra A, Bindraban PS (2014) Eliminating zinc deficiency in rice-based systems. VFRC Report 2014/2 Virtual Fertilizer Research Center, Washington DC, USA, pp 35

Duffy BK, Defago G (1999) Environmental factors modulating antibiotic and siderophore biosynthesis by Pseudomonas fluorescens biocontrol strains. Appl Environ Microbiol 65:2429-2438

Eggert K, von Wirén N (2013) Dynamics and partitioning of the ionome in seeds and germinating seedlings of winter oilseed rape. Metallomics 5:1316. doi:10.1039/C3MT00109A

Ekholm P, Eurola M, Venalainen E-R (2005) Selenium content of foods and diets in Finland. In: Eurola M (ed) Proceedings twenty years of selenium fertilization. Agrifood Res Rep 69, pp 39-45

Erisman JW, Sutton MA, Galloway JN, Klimont Z, Winiwarter W (2008) How a century of ammonia synthesis changed the world. Nat Geosci 1:636-639. doi:10.1038/ngeo325

Evans I, Solberg E, Huber DM (2007) Copper and plant diseases. In: Datnoff LE, Elmer WH, Huber DM (eds) Mineral nutrition and plant disease. American Phytopathological Society, St. Paul, pp 177-188

Fageria VD (2001) Nutrient interactions in crop plants. J Plant Nutr 24: 1269-1290. doi:10.1081/PLN-100106981

Fageria NK (2002) Influence of micronutrients on dry matter yield and interaction with other nutrients in annual crops. Pesq agropec bras Brasília 37:1765-1772

Faisal M, Saquib Q, Alatar AA, Al-Khedhairy AA, Hegazy AK, Musarrat J (2013) Phytotoxic hazards of NiO-nanoparticles in tomato: a study on mechanism of cell death. J Hazard Mater 250:318-332. doi:10. 1016/j.jhazmat.2013.01.063

Fan MS, Zhao FJ, Fairweather-Tait SJ (2008) Evidence of decreasing mineral density in wheat grain over the last 160 years. J Trace Elements Med Biol 22:315-324. doi:10.1016/j.jtemb.2008.07.002

Fernandez V, Ebert G, Winkelmann G (2005) The use of microbial siderophores for foliar iron application studies. Plant Soil 272: 245-252. doi:10.1007/s11104-5212-2

Fitzpatrick KL, Tyerman SD, Kaiser BN (2008) Molybdate transport through the plant sulfate transporter SHST1. FEBS Lett 582:15081513. doi:10.1016/j.febslet.2008.03.045

Gardea-Torresdey JL, Rico CM, White JC (2014) Trophic transfer, transformation, and impact of engineered nanomaterials in terrestrial environments. Environ Sci Technol 48:2525-2540. doi:10.1021/ es4050665 
Garvin DF, Welch RM, Finley JW (2006) Historical shifts in the seed mineral micronutrient concentration of US hard red winter wheat germplasm. J Sci Food Agric 86:2213-2220. doi:10.1002/jsfa.2601

Ghafariyan MH, Malakouti MJ, Dadpour MR, Stroeve P, Mahmoudi M (2013) Effects of magnetite nanoparticles on soybean chlorophyll. Environ Sci Technol 47:10645-10652. doi:10.1021/es402249b

Ghasemi-Fasaei R, Ronaghi A (2008) Interaction of iron with copper, zinc, and manganese in wheat as affected by iron and manganese in a calcareous soil. J Plant Nutr 31:839-848. doi:10.1080/ 01904160802043148

Gheibi MN, Kholdebarin B, Malakouti MJ, Ghanati F, Teimouri S, Sayadi R (2011) Effect of various nickel levels on growth and chlorophyll content of corn plants supplied with urea and ammonium nitrate. J Food, Agric Environ 9:583-587

Golldack D, Li C, Mohan H, Probst N (2014) Tolerance to drought and salt stress in plants: unraveling the signaling networks. Front Plant Sci 5:151. doi:10.3389/fpls.2014.00151

Graedel TE, Keene WC (1996) The budget and cycle of earth's natural chlorine. Pure Appl Chem 68:1689-1697. doi:10.1351/ pac199668091689

Graham RD, Welch RM, Saunders DA, Ortiz-Monasterio I, Bouis HE, Bonierbale M (2007) Nutritious subsistence food systems. Adv Agron 92:1-74. doi:10.1016/S0065-2113(04)92001-9

Grewal HS, Graham RD, Rengel Z (1996) Genotypic variation in zinc efficiency and resistance to crown rot disease (Fusarium graminearum Schw. Group 1) in wheat. Plant Soil 186:219-226. doi:10.1007/BF02415517

Habib M (2009) Effect of foliar application of $\mathrm{Zn}$ and Fe on wheat yield and quality Afr J Biotechnol 8:6795-6798

Hasani M, Zamani Z, Savaghebi G, Fatahi R (2012) Effects of zinc and manganese as foliar spray on pomegranate yield, fruit quality and leaf minerals. J Soil Sci Plant Nutr 12:3. doi:10.4067/S071895162012005000009

He L, Liu Y, Mustapha Z, Lin M (2012) Antifungal activity of zinc oxide nanoparticles against Botrytis cinerea and Penicillium expansum. Microbiol Res 166:207-215. doi:10.1016/j.micres.2010.03.003

Hignett TP, McClellan GH (1985) Source and production of micronutrients. In: Vlek PLG (ed) Micronutrients in tropical foods. Martinus Nijhoff/Dr W Junk, Dordrecht, pp 237-260

Holden PA, Klaessig F, Turco RF, Priester JH, Rico CM, Avila-Arias H, Mortimer M, Pacpaco K, Gardea-Torresdey JL (2014) Evaluation of exposure concentrations used in assessing manufactured nanomaterial environmental hazards: are they relevant? Environ Sci Technol 48:10541-10551. doi:10.1021/es502440s

Hossain B, Hirata N, Nagatomo Y, Akashi R, Takaki H (1997) Internal zinc accumulation is correlated with increased growth in rice suspension culture. J Plant Growth Reg 16:239-243. doi:10.1007/ PL00007003

Hosseini H, Khoshgoftarmanesh AH (2013) The effect of foliar application of nickel in the mineral form and urea-Ni complex on fresh weight and nitrogen metabolism of lettuce. Scientia Horticulturae 164:178-182. doi:10.1016/j.scienta.2013.09.030

Huang S, Wang L, Liu L, Hou Y, Li L (2015) Nanotechnology in agriculture, livestock and aquaculture. Agron Sustain Dev 33:369-400. doi:10.1007/s13593-014-0274-x

Huber DM, Wilhelm NS (1988) The role of manganese in disease resistance. In: Graham RD, Hannam RJ, Uren NC (eds) Manganese in soils and plants. Kluwer Academic, London, pp 155-173

Ishimaru Y, Suzuki M, Kobayashi T, Takahashi M, Nakanishi H, Mori S, Nishizawa NK (2005) OsZIP4, a novel zinc-regulated zinc transporter in rice. J Exp Bot 56:3207-3214. doi:10.1093/jxb/eri317

Javadi M, Beuerlein JE, Arscott TG (1991) Effects of phosphorus and copper on factors influencing nutrient uptake, photosynthesis and grain yield of wheat. Ohio J Sci 91:5
Johnson GV, Barton LL (2007) Inhibition of iron deficiency stress response in cucumber by rare earth elements. Plant Physiol Biochem 45:302-308. doi:10.1016/j.plaphy.2007.03.012

Jones DL, Cross P, Withers PJA, DeLuca TH, Robinson DA, Quilliam RS, Harris IM, Chadwick DR, Edwards-Jones G (2013) Review: nutrient stripping: the global disparity between food security and soil nutrient stocks. J Applied Ecol 50:851-862. doi:10.1111/ 1365-2664.12089

Joy EJM, Ander EL, Young SD, Black CR, Watts MJ, Chilimba ADC, Chilima B, Siyame EWP, Kalimbira AA, Hurst R, Fairweather-Tait SJ, Stein AJ, Gibson RS, White PJ, Broadley MR (2014) Dietary mineral supplies in Africa. Physiol Plantarum 151:208-229. doi:10. 1111/ppl.12144

Joy EJM, Stein AJ, Young SD, Ander EL, Watts MJ, Broadley MR (2015) Zinc-enriched fertilisers as a potential public health intervention in Africa. Plant Soil 389:1-24. doi:10.1007/s11104-015-2430-8

Jozedaemi E, Golchin A, Bibalani GH (2012) The effect of soil and foliar fertilization with iron on yield and leaf chemical composition of four spotted bean cultivars in a calcareous soil. Greener J Biol Sci 4:116 127

Kanwar JS, Youngdahl JJ (1985) Micronutrient needs of tropical food crops. In: Vlek PLG (ed) Micronutrients in tropical foods. Martinus Nijhoff/Dr W. Junk, Dordrecht, pp 43-67

Katyal JC, Ponamperuma FN (1974) Zinc deficiency: a widespread nutritional disorder in rice in Agusan del Norte. Philippines Agric 58: 79-89

Keuskamp DH, Kimber R, Bindraban PS, Dimkpa CO, Schenkeveld WDC (2015) Plant exudates for nutrient uptake. VFRC Report 2015/4. Virtual Fertilizer Research Center, Washington DC, USA, pp 53

Khoshgoftarmanesh AH, Behzadan HZ, SanaeiOstovar A, Chaney RL (2012) Bacterial inoculation speeds zinc release from ground tire used as $\mathrm{Zn}$ fertilizer for corn and sunflower in a calcareous soil. Plant Soil 361:71-81. doi:10.1007/s11104-012-1303-7

Khoshgoftarmanesh AH, SanaeiOstovar A, Sadrarhami A, Chaney RL (2013) Effect of tire rubber ash and zinc sulfate on yield and grain zinc and cadmium concentrations of different zinc-deficiency tolerance wheat cultivars under field conditions. Euro, J Agron 49:4249. doi:10.1016/j.eja.2013.02.013

Kim SA, Guerinot ML (2007) Mining iron, iron uptake and transport in plants. FEB Lett 581:2273-2280. doi:10.1016/j.febslet.2007.04.043

Kim JH, Lee Y, Kim EJ, Gu S, Sohn EJ, Seo YS, An HJ, Chang YS (2014) Exposure of iron nanoparticles to Arabidopsis thaliana enhances root elongation by triggering cell wall loosening. Environ Sci Technol 48:3477-3485. doi:10.1021/es4043462

Kleiber T (2014) Changes of nutrient contents in tomato fruits under the influence of increasing intensity of manganese nutrition. Ecol Chem Eng S 21:297-307. doi:10.2478/eces-2014-0023

Kloepper JW, Leong J, Teintze M, Schroth MN (1980) Pseudomonas siderophores - a mechanism explaining disease-suppressive soils. Curr Microbiol 4:317-320. doi:10.1007/BF02602840

Kouhi SMM, Lahouti M, Ganjeali A, Entezari MH (2014) Comparative phytotoxicity of $\mathrm{ZnO}$ nanoparticles, $\mathrm{ZnO}$ microparticles, and $\mathrm{Zn} 2^{+}$ on rapeseed (Brassica napus L.): investigating a wide range of concentrations. Toxicol Environ Chem 96:861-868. doi:10.1080/ 02772248.2014.994517

Kumar R, Mehrotra NK, Nautiyal BD, Kumar P, Singh PK (2009) Effect of copper on growth, yield and concentration of $\mathrm{Fe}, \mathrm{Mn}, \mathrm{Zn}$ and $\mathrm{Cu}$ in wheat plants (Triticum aestivum L.). J Environ Bio 30:485-488

Kumssa DB, Joy EJM, Ander EL, Watts MJ, Young SD, Walker S, Broadley MR (2015) Dietary calcium and zinc deficiency risks are decreasing but remain prevalent. Scientific Rep 5:10974. doi:10. 1038/srep10974

Lim HS, Kim SD (1997) Role of siderophores in biocontrol of Fusarium solani and enhanced growth response of bean by Pseudomonas fluorescens GL20. J Microbiol Biotech 7:12-20 
Liu R, Lal R (2014) Synthetic apatite nanoparticles as a phosphorus fertilizer for soybean (Glycine max). Scientific Rep 4:5686. doi:10. 1038/srep05686

Liu R, Lal R (2015) Potentials of engineered nanoparticles as fertilizers for increasing agronomic productions. Sci Total Environ 514:131139. doi:10.1016/j.scitotenv.2015.01.104

Liu L, Chen B, Wang QL, Shi XL, Xiao ZY, Lin JX, Fang XH (2009) Carbon nanotubes as molecular transporters for walled plant cells. Nano Lett 9:1007-1010. doi:10.1021/n1803083u

Liverpool-Tasie LSO, Omonona BT, Sanou A, Ogunleye W (2015) Is increasing inorganic fertilizer use in Sub-Saharan Africa a profitable proposition? Evidence from Nigeria. World Bank Group. Policy research working paper No. 7201. http://www-wds.worldbank.org/ external/default/WDSContentServer/WDSP/IB/2015/02/24/ 000158349_20150224133552/Rendered/PDF/WPS7201.pdf. Accessed 9 Nov 2015

LV J, Zhang S, Luo L, Zhang J, Yang K, Christie P (2014) Accumulation, speciation, and uptake pathway of $\mathrm{ZnO}$ nanoparticles in maize. Environ Sci: Nano 2:68-77. doi:10.1039/C4EN00064A

Mallarino AP, Oltmans RR, Prater JR, Villavicencio CX (2011) Nutrient uptake by corn and soybean, removal and recycling with crop residue. Integr Crop Manage Conf, Iowa State University No. 103. http://www.agronext.iastate.edu/soilfertility/info/mallarino-2.pdf. Accessed 9 Nov 2015

Marschner P (2012) Marschner's mineral nutrition of higher plants, 3rd edn. Elsevier, Oxford

Martineau N, McLean JE, Dimkpa CO, Britt DW, Anderson AJ (2014) Components from wheat roots modify the bioactivity of $\mathrm{ZnO}$ and $\mathrm{CuO}$ nanoparticles in a soil bacterium. Environ Pollut 187:65-72. doi:10.1016/j.envpol.2013.12.022

Martínez-Ballesta MC, Dominguez-Perles R, Moreno DA, Muries B, Alcaraz-L pez C, Bastías E, García-Viguera C, Carvajal M (2010) Minerals in plant food: effect of agricultural practices and role in human health. A review. Agron Sustain Dev 30:295-309. doi:10. 1051/agro/2009022

Matraszek R, Szymańska M, Wr blewska M (2002) Effect of nickel on yield and mineral composition of selected vegetables. Hortorum Cultus 1:13-22

Mayer AM (1997) Historical changes in the mineral content of fruits and vegetables. British Food J 99:207-211. doi:10.1108/ 00070709710181540

McBeath TM, McLaughlin MJ (2014) Efficacy of zinc oxides as fertilisers. Plant Soil 374:843-885. doi:10.1007/s11104-013-1919-2

McClafferty B, Zuckermann JC (2015) Cultivating nutritious food systems: a snapshot report. Global Alliance for Improved Nutrition (GAIN), Washington, p 47

McKenzie RH (2001) Micronutrient requirements of crops. Alberta Agriculture and Rural Development. http://www1.agric.gov.ab.ca/ \$department/deptdocs.nsf/all/agdex713. Accessed 9 Nov 2015

Mendel RR, Schwarz G (1999) Molybdoenzymes and molybdenum cofactor in plants. Crit Rev Plant Sci 18:33-69. doi:10.1080/ 07352689991309180

Milani N, McLaughlin MJ, Stacey SP, Kirby JK, Hettiarachchi GM, Beak DG, Cornelis G (2012) Dissolution kinetics of macronutrient fertilizers coated with manufactured zinc oxide nanoparticles. J Agric Food Chem 60:3991-3998. doi:10.1021/jf205191y

Milani N, Hettiarachchi GM, Kirby JK, Beak DG, Stacey SP, McLaughlin MJ (2015) Fate of zinc oxide nanoparticles coated onto macronutrient fertilizers in an alkaline calcareous soil. PLoS One 10, e0126275. doi:10.1371/journal.pone.0126275

Mishra AK, Shukla SK, Yadav DV, Awasthi SK (2014) Iron, manganese and sulphur uptake and nutrients availability in sugarcane based system in subtropical India. Sugar Tech 16:300-310. doi:10.1007/ s12355-013-0269-y
Mitani N, Yamaji N, Ma JF (2008) Characterization of substrate specificity of a rice silicon transporter, Lsil. Pflugers Archiv-Euro J Physiol 456:679-686. doi:10.1007/s00424-007-0408-y

Miwa K, Fujiwara T (2010) Boron transport in plants: co-ordinated regulation of transporters. Ann Bot 105:1103-1108. doi:10.1093/aob/ meq044

Moghaddasi S, Khoshgoftarmanesh AH, Karimzadeh F, Chaney RL (2013) Preparation of nano-particles from waste tire rubber and evaluation of their effectiveness as zinc source for cucumber in nutrient solution culture. Sci Horticul 160:398-403. doi:10.1016/j. scienta.2013.06.028

Molden D, Oweis T, Steduto P, Bindraban PS, Hanjra MA, Kijne J (2010) Improving agricultural water productivity: between optimism and caution. Agric Water Manag 97:528-535. doi:10.1016/j.agwat. 2009.03.023

Monasterio I, Graham RD (2000) Breeding for trace mineral in wheat Food Nutr Bull 21:392-396. doi:10.1177/156482650002100409

Monreal CM, DeRosa M, Mallubhotla SC, Bindraban PS, Dimkpa CO (2015) Nanotechnologies for increasing the crop use efficiency of fertilizer-micronutrients. Biol Fert Soils. doi:10.1007/s00374-0151073-5

Movahhedy-Dehnavy M, Modarres-Sanavy SAM, Mokhtassi-Bidgoli A (2009) Foliar application of zinc and manganese improves seed yield and quality of safflower (Carthamus tinctorius $\mathrm{L}$ ) grown under water deficit stress. Industr Crops Products 30:82-92. doi:10.1016/j. indcrop.2009.02.004

Mukherjee I, Campbell NH, Ash JH, Connolly EL (2006) Expression profiling of the Arabidopsis ferric chelate reductase (FRO) gene family reveals differential regulation by iron and copper. Planta 223:1178-1190. doi:10.1007/s00425-005-0165-0

Muthikumararaja T, Sriramachandrasekharan MV (2012) Critical limit of zinc for rice soils of Veeranam Command Area, Tamilnadu, India. ARPN J Agric Biol Sci 7:1

Nadim MA, Awan IU, Baloch MS, Khan EA, Naveed K, Khan MA (2012) Response of wheat (Triticum aestivum L.) to different micronutrients and their application methods. J Animal Plant Sci 22:113-119

Nair R, Varghese SH, Nair BG, Maekawa T, Yoshida Y, Kumar DS (2010) Nanoparticulate material delivery to plants. Plant Sci 179: 154-163. doi:10.1016/j.plantsci.2010.04.012

Nestel P, Bouis HE, Meenakshi JV, Pfeiffer W (2006) Biofortification of staple food. J Nutrit 136:1064-1067

Norvell WA, Welch RM, Adams ML, Kochain LV (1993) Reduction of $\mathrm{Fe}(\mathrm{III}), \mathrm{Mn}(\mathrm{III})$, and $\mathrm{Cu}(\mathrm{II})$ chelates by roots of pea (Pisumsativum L) or soybean (Glycine max). Plant Soil 155:123-126. doi:10.1007/ BF00024999

Obrador A, Gonzalez D, Alvarez JM (2013) Effect of inorganic and organic copper fertilizers on copper nutrition in Spinacia oleracea and on labile copper in soil. J Agric Food Chem. 61:4692-701. doi: 10.1021/jf305473f

Oliver MA, Gregory PJ (2015) Soil, food security and human health: a review. Euro J Soil Sci 66:257-276. doi:10.1111/ejss.12216

Pande P, Chand S, Pandey A, Patra DD (2011) Effect of sole and conjoint application of iron and manganese on herb yield, nutrient uptake, oil quality vis-à-vis their optimal level in spearmint (Mentha spicata Linn. Emend Nathh. Cv. 'Arka'). Indian J Nat Prod Res 2:242-249

Paschke MW, Redente EF (2002) Copper toxicity thresholds for important restoration grass species of the western United States. Environ Toxicol Chem 21:2692-2697. doi:10.1002/etc.5620211223

Paschke MW, Perry LG, Redente EF (2006) Zinc toxicity thresholds for reclamation forb species. Water, Air, Soil Pollut 170:317-330. doi: 10.1007/s11270-006-3139-3

Pestana M, Correia PJ, Saavedra T, Gama F, Abadia A, de Varennes A (2012) Development and recovery of iron deficiency by iron resupply to roots or leaves of strawberry plants. Plant Physiol Biochem 53:1-5. doi:10.1016/j.plaphy.2012.01.001 
Phattarakul N, Rerkasem B, Li LJ, Wu LH, Zou CQ, Ram H, Sohu VS, Kang BS, Surek H, Kalayci M, Yazici A, Zhang FS, Cakmak I (2012) Biofortification of rice grain with zinc through zinc fertilization in different countries. Plant Soil 361:131-141. doi:10.1007/ s11104-012-1211-x

Podleśna A (2009) Effect of fertilization on content and uptake of chlorine by oilseed rape under pot experiment conditions. J Elementol 14: 773-778

Polaccao J, Freyermuth S, Gerendas J, Cianzio S (1999) Soybean genes involved in nickel insertion into urease. J Exp Bot 50:1149-1156. doi:10.1093/jxb/50.336.1149

Pradhan S, Patra P, Das S, Chandra S, Mitra S, Dey KK (2013) Photochemical modulation of biosafe manganese nanoparticles on Vigna radiata: a detailed molecular, biochemical, and biophysical study. Environ Sci Technol 47:13122-13131. doi:10.1021/ es402659t

Prasad TNVKV, Sudhakar P, Sreenivasulu Y, Latha P, Munaswamy V, Reddy KR, Sreeprasad TS, Sajanlal PR, Pradeep T (2012) Effect of nanoscale zinc oxide particles on the germination, growth and yield of peanut. J Plant Nutr 35:905-927. doi:10.1080/01904167.2012. 663443

Puga AP, Prado RM, Fonseca IM, Vale DW, Avalhães CC (2013) Ways of applying zinc to maize plants growing in oxisol: effects on the soil, on plant nutrition and on yield. Idesia (Arica) 31:29-37

Radzki W, Gutierrez Mañero FJ, Algar E, Lucas García JA, GarcíaVillaraco A, Ramos Solano B (2013) Bacterial siderophores efficiently provide iron to iron-starved tomato plants in hydroponics culture. Antonie van Leeuwenhoek 104:321-330. doi:10.1007/ s10482-013-9954-9

Rajeev P, Dinesh K (2014) Influence of soil and foliar applied boron on green gram in calcareous soils. Int J Agric Environ Biotechnol 7: 129-136. doi:10.5958/j.2230-732X.7.1.018

Raliya R, Tarafdar JC (2013) ZnO nanoparticle biosynthesis and its effect on phosphorous-mobilizing enzyme secretion and gum contents in clusterbean (Cyamopsis tetragonoloba L). Agric Res 2:48-57. doi: 10.1007/s40003-012-0049-Z

Ramegowda V, Senthil-Kumar M (2015) The interactive effects of simultaneous biotic and abiotic stresses on plants: mechanistic understanding from drought and pathogen combination. J Plant Physiol 176:47-54. doi:10.1016/j.jplph.2014.11.008

Reid R (2014) Understanding the boron transport network in plants. Plant Soil 385:187-198. doi:10.1007/s11104-014-2149-y

Rellán-Álvarez R, López-Gomollón S, Javier Abadía J, ÁlvarezFernández A (2011) Development of a new high-performance liquid chromatography-electrospray ionization time-of-flight mass spectrometry method for the determination of low molecular mass organic acids in plant tissue extracts. J Agric Food Chem 59:68646870. doi:10.1021/jf200482a

Rietra RPJJ, Heinen M, Dimkpa CO, Bindraban PS (2015) Effects of nutrient antagonism and synergism on fertilizer use. VFRC Report 2015/5. Virtual Fertilizer Research Center, Washington, DC, USA, pp 42

Robinson NJ, Proctor CM, Connolly EL, Guerinot ML (1999) A ferricchelate reductase for iron uptake from soils. Nature 397:694-697. doi: $10.1038 / 17800$

Rodriguez-Lucena P, Hernandez-Apaolaza L, Lucena JJ (2010) Comparison of iron chelates and complexes supplied as foliar sprays and in nutrient solution to correct iron chlorosis of soybean. J Plant Nutri Soil Sci 173:120-126. doi:10.1002/jpln.200800256

Römheld V, Marschner H (1991) Function of micronutrients in plants. In: Mortvedt JJ, Cox FR, Shuman LM, Welch RM (eds) Micronutrients in agriculture. Soil Science Society of America, Madison, pp 297 328

Ros GH, van Rotterdam AMD, Doppenberg GD, Bussink DW, Bindraban PS (2014) Se fertilization: an agro-ecosystem approach.
VFRC Report 2014/3. Virtual Fertilizer Research Center, Washington DC, USA, pp 62

Ryan BM, Kirby JK, Degryse F, Harris H, McLaughlin MJ, Scheiderich $\mathrm{K}$ (2013a) Copper speciation and isotope fractionation in plants, uptake and translocation mechanisms. New Phytol 199:367-368. doi:10.1111/nph.12276

Ryan J, Rashid A, Torrent J, Yau SK, Ibrikci H, Sommer R, Erenoglu EB, Sparks DL (2013b) Micronutrient constraints to crop production in the Middle East-West Asia region: significance, research and management. Adv Agron 122:1-84. doi:10.1016/b978-0-12-417187-9. 00001-2

Samourgiannidis G, Matsi T (2013) Comparison of two sequential extraction methods and the dtpa method for the extraction of micronutrients from acidic soils. Commun Soil Sci Plant Anal 44: 38-49. doi:10.1080/00103624.2012.734030

Schaaf G, Erenoglu BE, von Wiren N (2004) Physiological and biochemical characterization of metal-phytosiderophore transport in graminaceous species. Soil Sci Plant Nutri 50:989-995. doi:10. 1080/00380768.2004.10408565

Seadh SE, EL-Abady MI, El-Ghamry AM, Farouk S (2009) Influence of micronutrients foliar application and nitrogen fertilization on wheat yield and quality of grain and seed. J Biol Sci 9:851-858

Servin A, Elmer W, Mukherjee A, De La Torre-Roche R, Hamdi H, White JC, Bindraban PS, Dimkpa CO (2015a) A review of the use of engineered nanomaterials to suppress plant disease and enhance crop yield. J Nanopart Res 17:92. doi:10.1007/s11051-015-2907-7

Servin A, Elmer W, Mukherjee A, De La Torre-Roche R, Hamdi H, White JC, Dimkpa C (2015b) Nanoscale micronutrients suppress disease. VFRC Report 2015/2. Virtual Fertilizer Research Center, Washington, DC, USA, pp 33

Shanmugam V, Lo JC, Wu CL, Wang SL, Lai CC, Connolly EL, Huang JL, Yeh KC (2011) Differential expression and regulation of ironregulated metal transporters in Arabidopsis halleri and Arabidopsis thaliana - the role in zinc tolerance. New Phytol 190:125-137. doi: 10.1111/j.1469-8137.2010.03606.x

Sheykhbaglou R, Sedghi M, Shishevan MT, Sharifi RS (2010) Effects of nano-iron oxide particles on agronomic traits of soybean. Not Sci Biol 2:112-113

Sharma P, Duveiller E, Sharma RC (2006) Effect of mineral nutrients on spot blotch severity in wheat and associated increases in grain yield. Field Crops Res 95:426-430. doi:10.1016/j.fcr.2005.04.015

Shirasu K, Lahaye T, Tan MW, Zhou FS, Azevedo C, Schulze-Lefert P (1999) A novel class of eukaryotic zinc-binding proteins is required for disease resistance signaling in barley and development in C. elegans. CELL 99:355-366. doi:10.1016/S0092-8674(00) 81522-6

Shivay YS, Kumar D, Prasad R, Ahlawat IPS (2008) Relative yield and zinc uptake by rice from zinc sulphate and zinc oxide coatings onto urea. Nutr Cycl Agroecosyst 80:181-188. doi:10.1007/s10705-0079131-5

Sims JL, Atkinson WO, Smitobol C (1975) Mo and N effects on growth, yield, and Mo composition of burley tobacco. Agron J 67:824-828. doi:10.2134/agronj1975.00021962006700060025x

Sinclair SA, Krämer U (2012) The zinc homeostasis network of land plants. Biochim Biophys Acta 1823:1553-67. doi:10.1016/j. bbamcr.2012.05.016

Singh D, Yadav S, Nautiyal N (2014) Evaluation of growth responses in wheat as affected by the application of zinc and boron to a soil deficient in available zinc and boron. Comm Soil Sci Plant Analysis 45:765-776. doi:10.1080/00103624.2013.858729

Sirko A, Brodzik R (2000) Plant ureases: roles and regulation. Acta Biochim Polon 47:1189-1195

Škarpa P, Kunzova E, Zukalova H (2013) Foliar fertilization with molybdenum in sunflower (Helianthus annuus L.). Plant Soil Environ 59: 156-161 
Slamet-Loedin IH, Johnson-Beebout SE, Impa S, Tsakirpaloglou N (2015) Enriching rice with $\mathrm{Zn}$ and Fe while minimizing Cd risk. Front Plant Sci 6:121. doi:10.3389/fpls.2015.00121

Sobral LF, Smyth JT, Fageria NK, Stone LF (2013) Comparison of copper, manganese and zinc extraction with Mehlich 1, Mehlich 3 and DTPA solutions for soils of the Brazilian coastal tablelands. Comm Soil Sci Plant Anal 44:2507-2513. doi:10.1080/00103624.2013. 812731

Sparrow DH, Graham RD (1988) Susceptibility of zinc-deficient wheat plants to colonization by Fusarium graminearum Schw. Group 1. Plant Soil 112:261-266. doi:10.1007/BF02140004

Stangoulis JCR, Graham RD (2007) Boron and plant disease. In: Datnoff LE, Elmer WH, Huber DM (eds) Mineral nutrition and plant disease. American Phytopathological Society, St. Paul, pp 139-153

Stewart J, Hansen T, McLean JE, McManus P, Das S, Britt DW, Anderson AJ, Dimkpa CO (2015) Salts affect the interaction of $\mathrm{ZnO}$ or $\mathrm{CuO}$ nanoparticles with wheat. Environ Toxicol Chem 34: 2116-2125. doi:10.1002/etc.3037

Taheri S, Khoshgoftarmanesh AH, Shariatmadari H, Chaney RL (2011) Kinetics of zinc release from ground tire rubber and rubber ash in a calcareous soil as alternatives to $\mathrm{Zn}$ fertilizers. Plant Soil 341:89-97. doi:10.1007/s11104-010-0624-7

Taran NY, Gonchar OM, Lopatko KG, Batsmanova LM, Patyka MV, Volkogon MV (2014) The effect of colloidal solution of molybdenum nanoparticles on the microbial composition in rhizosphere of Cicer arietinum L. Nanoscale Res Lett 9:289. doi:10.1186/1556276X-9-289

Tariq A, Anjum SA, Randhawa MA, Ullah E, Naeem M, Qamar R, Ashraf U, Nadeem M (2014) Influence of zinc nutrition on growth and yield behaviour of maize (Zea mays L.) hybrids. Ame J Plant Sci 5:2646-2654. doi:10.4236/ajps.2014.518279

Tilman D, Balzer C, Hill J, Befort BL (2011) Global food demand and the sustainable intensification of agriculture. Proc Natl Acad Sci U S A 108:20260-20264. doi:10.1073/pnas.1116437108

Timilsena YP, Adhikari R, Casey P, Muster T, Gill H, Adhikaria B (2015) Enhanced efficiency fertilisers: a review of formulation and nutrient release patterns. J Sci Food Agric 95:1131-1142. doi:10.1002/jsfa. 6812

Tomatsu H, Takano J, Takahashi H, Watanabe-Takahashi A, Shibagaki N, Fujiwara T (2007) An Arabidopsis thaliana high-affinity molybdate transporter required for efficient uptake of molybdate from soil. Proc Natl Acad Sci U S A 104:18807-18812. doi:10.1073/pnas. 0706373104

United Nations (2013) World population prospects: the 2012 revision, highlights and advance tables. United Nations, New York, USA. http://esa.un.org/unpd/wpp/Publications/Files/WPP2012 HIGHLIGHTS.pdf. Accessed 9 Nov 2015

United States Geological Survey (2014) Mineral commodity summaries. USGS, Virginia, USA www.minerals.usgs.gov/minerals/pubs/mcs. Accessed 9 Nov 2015

Vanlauwe B, Bationo A, Chianu J, Giller KE, Merckx R, Mokwunye U (2010) Integrated soil fertility management: operational definition and consequences for implementation and dissemination. Outlook Agric 39:17-24. doi:10.5367/000000010791169998

Vanlauwe B, Descheemaeker K, Giller K, Huising J, Merckx R, Nziguheba G, Wendt J, Zingore S (2014) Integrated soil fertility management in Sub-Saharan Africa: unravelling local adaptation. Soil Discuss 1:1239-1286. doi:10.5194/soild-1-1239-2014

Vansuyt G, Robin A, Briat JF, Curie C, Lemanceau P (2007) Iron acquisition from Fe-pyoverdine by Arabidopsis thaliana. Mol Plant Microbe Interact 20:441-447. doi:10.1094/MPMI-20-4-0441
Vaseghi S, Valinejad M, Afzali M (2013) Boron fertilizer effects on soybean yield, leaf and boron concentration in seed. World Sci J 01: 178-188

Velu G, Ortiz-Monasterio I, Cakmak I, Hao Y, Singh RP (2014) Biofortification strategies to increase grain zinc and iron concentrations in wheat. J Cereal Sci 59:365-372. doi:10.1016/j.jcs.2013.09. 001

Voortman R, Bindraban PS (2015) Beyond N and P: toward a land resource ecology perspective and impactful fertilizer interventions in Sub-Saharan Africa. VFRC Report 2015/1. Virtual Fertilizer Research Center, Washington, DC, USA, pp 49

Wang JW, Mao H, Zhao HB, Huang DL, Wang ZH (2012a) Different increases in maize and wheat grain zinc concentrations caused by soil and foliar applications of zinc in Loess Plateau, China. Field Crops Res 135:89-96. doi:10.1016/j.fcr.2012.07.010

Wang Z, Xie X, Zhao J, Liu X, Feng W, White JC, Xing B (2012b) Xylem- and phloem-based transport of $\mathrm{CuO}$ nanoparticles in maize (Zea mays L). Environ Sci Technol 46:4434-4441. doi:10.1021/ es204212z

Wang J, Koo Y, Alexander A, Yang Y, Westerhof S, Zhang O et al (2013a) Phytostimulation of poplars and Arabidopsis exposed to silver nanoparticles and $\mathrm{Ag}^{+}$at sublethal concentrations. Environ Sci Technol 47:5442-5449. doi:10.1021/es4004334

Wang WN, Tarafdar JC, Biswas P (2013b) Nanoparticle synthesis and delivery by an aerosol route for watermelon plant foliar uptake. J Nanopart Res 15:1417. doi:10.1007/s11051-013-1417-8

Waters BM, Sankaran RP (2011) Moving micronutrients from the soil to the seeds: genes and physiological processes from a biofortification perspective. Plant Sci 180:562-574. doi:10.1016/j.plantsci.2010.12. 003

Watson J-L, Fang T, Dimkpa CO, Britt DW, McLean JE, Jacobson A, Anderson AJ (2015) The phytotoxicity of $\mathrm{ZnO}$ nanoparticles on wheat varies with soil properties. Biometals 28:101-112. doi:10. 1007/s10534-014-9806-8

Welch RM, Graham RD (2002) Breeding crops for enhanced micronutrient content. Plant Soil 245:205-214. doi:10.1023/ A: 1020668100330

White PJ, Broadley MR (2005) Historical variation in the mineral composition of edible horticultural products. J Horticul Sci Biotech 80: 660-667

White PJ, Broadley MR (2009) Biofortification of crops with seven mineral elements often lacking in human diets - iron, zinc, copper, calcium, magnesium, selenium and iodine. New Phytol 182:49-84. doi:10.1111/j.1469-8137.2008.02738.x

White PJ, Brown PH (2010) Plant nutrition for sustainable development and global health. Ann Bot 105:1073-1080. doi:10.1007/s11104010-0677-7

White PJ, George TS, Dupuy LX, Karley AJ, Valentine TA, Wiesel L, Wishart J (2013) Root traits for infertile soils. Front Plant Sci 4:193. doi:10.3389/fpls.2013.00193

Wilhelm NS, Graham RD, Rovira AD (1988) Application of different sources of manganese sulfate decreases take-all (Gaeumannomyces graminis var. tritici) of wheat grown in a manganese deficient soil. Aust J Agric Res 39:1-10. doi:10.1071/AR9880001

Wuana A, Okieimen FE (2011) Heavy metals in contaminated soils: a review of sources, chem., risks and best available strategies for remediation. ISRN Ecol 10:5402-402647. doi:10.5402/2011/402647

Yadav HK, Dogra P, Yadav V (2014) Effect of foliar application of N and $\mathrm{Zn}$ on growth and yield of cauliflower (Brassica oleracea var. botrytis L.) cv Snowball. Agric Sust Dev 2:56-58 
Yaseen M, Ahmed W, Shahbaz M (2013) Role of foliar feeding of micronutrients in yield maximization of cotton in Punjab. Turkish J Agric Forestr 37:420-426. doi:10.3906/tar-1206-56

Yruela I (2009) Copper in plants: acquisition, transport and interactions. Funct Plant Biol 26:409-430. doi:10.1071/FP08288

Zabrieske Z, Morrell E, Hortin J, Dimkpa C, McLean J, Britt D, Anderson A (2015) Pesticidal activity of metal oxide nanoparticles on plant pathogenic isolates of Pythium. Ecotoxicol 24:1305-1314. doi:10.1007/s10646-015-1505-x
Zhang M, Ellis EA, Cisneros-Zevallos L, Akbulut M (2012) Uptake and translocation of polymeric nanoparticulate drug delivery systems into ryegrass. RSC Adv 2:9679-9686. doi:10.1039/C2RA21469E

Zhu H, Han J, Xiao JQ, Jin Y (2008) Uptake, translocation, and accumulation of manufactured iron oxide nanoparticles by pumpkin plants. J Environ Monitor 10:713-717. doi:10.1039/B805998E

Zou CQ, Zhang YQ, Rashid A, Ram H, Savasli E, Arisoy RZ (2012) Biofortification of wheat with zinc through zinc fertilization in seven countries. Plant Soil 361:119-130. doi:10.1007/s11104-012-1369-2 